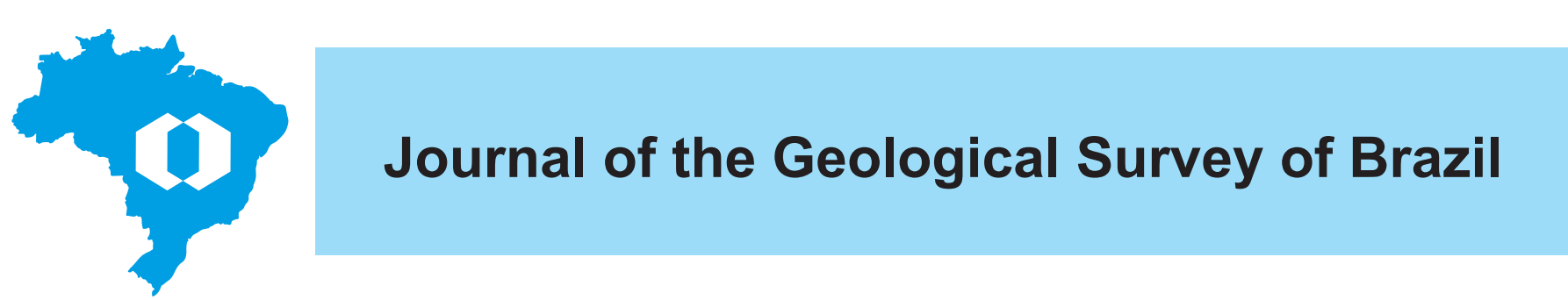

\title{
The corridor of mineralization in the California gold district, in the Santander Department of Colombia
}

\author{
Wilson Scarpelli ${ }^{* *}$ (1) \\ ${ }^{1}$ Independent consultant. Rua da Paz 119, Cotia-SP, Brazil, CEP: 06710-507
}

\begin{abstract}
In the Santander Massif of the Eastern Cordillera of Colombia, intense Pliocene to Holocene sulfide-rich gold mineralization occurs in a six kilometers long section of the La Baja fault zone, where it crosses partially migmatized gneisses and intrusions of Triassic-Cretaceous quartz monzonites and granites. These intrusives are mineralogically and texturally similar to the neosome of the migmatites that they intrude. The mineralization occurs as medium to large veins in the gneisses and as small veins, veinlets and disseminations in the intrusives. The type, volume and metal grades of the veins are dependent on the local structure, and the chemical composition and degree of reactivity of the host rocks. Thicker and higher-grade veins of the Mascota-type occur in chemically favorable magnetite-hornblende gneisses and migmatites, deposited after phases of silicification, and brecciation along the foliation of the host rocks. The Gigante-type shear veins occur in splays of the fault, and are marked by shearing and mylonitization. Lower-grade, flat-banded veins appear in leucocratic quartz-feldspar gneiss and related migmatites. The mineralizing fluids ascended along fault planes, and invaded the gneisses in fractures oblique to them. In all deposits, gold occurs in free form, as electrum and in tellurides, and accompanied by copper and silver.
\end{abstract}

Article Information

Publication type: Research papers Received 17 November 2020 Accepted 4 February 2021 Online pub. 15 March 2021 Editor: C. Spier

Keywords:

Andean Precambrian gneisses,

Auriferous magnetite-hornblende gneiss, Fault veins, Breccia veins,

Collision of Caribbean and Pacific Plates

${ }^{*}$ Corresponding author

Wilson Scarpelli

E-mail address: wiscar@terra.com.br

\section{Introduction}

In the Municipality of California, Department of Santander, Colombia, there is a widespread gold mineralization, with an intense concentration of deposits in a six kilometers long corridor following the La Baja fault zone, where it crosses a sequence of partially migmatized Precambrian gneisses and Triassic-Cretaceous granitic intrusives (Figs. 1 and 2, which are described further on). The mineralization is sulfide-rich and has been interpreted as forming part of a large epithermal system of high- to intermediate sulfidation (Bissig et al. 2015, Rodríguez Madrid et al. 2017). The gold mineralization occurs in all lithologies of the corridor, but with distinct features, textures, grades and sizes. This contribution aims to present a literature review about the geology of gold mineralizations in the California auriferous corridor and report a large amount of geological data that I and the geological team of AUX, led by me, collected during the exploration work of the distinct geological environments of the area. The various types of veins are here described with details of their structural and lithological controls, in particular, those hosted in a magnetitehornblende gneiss, the most highly mineralized rock of the area. The description of the mineralization is completed with the presentation of a model for the origin of the veins, providing a basis for future exploration for vein extensions and additional veins. This information may help the identification of other styles of gold mineralization in the region.

The article begins with a summary of the historical development of the exploration of the area. This is followed by a review of the lithological and tectonic setting of North Colombia, outlining the possible and important participation or influence of the Caribbean Plate in the mineralization.

\section{Exploration and mining history}

Gold mineralization in the area was first described decades ago (Ward et al. 1970), but, for most of the time, the main activity was conducted by small mine entrepreneurs, exploiting shallow portions of some veins. Over the years, major mining companies visited the area looking for porphyrytype deposits. They focused on granitic intrusives, such as the Pié de Gallo, and, more recently, on those of Angostura, which are currently under exploration by Eco Oro Minerals Corp. (Eco Oro Minerals Corp 2018). 
The veins remained poorly studied until 2005, when Geologist Jon Lehmann of Ventana Gold Corp. recognized their potential. After obtaining mineral rights covering a part of the favorable area, Ventana conducted exploration that culminated in a 43-101 compliant inferred resource of 28 million tons at $3.88 \mathrm{~g} / \mathrm{t} \mathrm{Au}, 21.49 \mathrm{~g} / \mathrm{t} \mathrm{Ag}$ and $0.14 \% \mathrm{Cu}$ (Altman et al. 2010). Early in 2011, the EBX Group acquired the complete project through its subsidiary; AUX Canada Acquisition Inc. AUX immediately intensified the exploration, increasing the resource base and exposing in detail the nature and controls of the auriferous veins described in this paper.

During 2012, after the conclusion of a positive feasibility study, AUX took measures to open an underground mine and build a mineral processing plant. On that occasion, AUX acquired from Galway Resources and Calvista Gold Corp. a group of concessions located at the southwest of the areas acquired from Ventana (Figs. 2, 3, and 4), and extended their exploration activities to these areas.

During 2012-2013, following the financial problems of their oil companies, EBX sold the project to Mubadala Development Co., of Abu Dhabi, United Arab Emirates, which then created Sociedade Minera de Santander, Minesa, to continue the project, renamed as Soto Norte. Recently, Minesa (Minesa 2017) informed a plan to begin exploitation in 2021, expecting to reach the total production of 9 million ounces of gold (ca. 280 tons of gold)) by the year 2044. Early in 2018, Minesa acquired from Eco Oro additional concessions to the northeast and southwest of the project area (Eco Oro Minerals Corp 2018).

The paper by Rodríguez Madrid et al. (2017), based on data and samples collected during the last days of work of Ventana in the area, is recommended to the interested reader. It gathers information from previous literature and presents a substantial and valuable volume of good new data on the gold mineralization, mineralogy of the deposits, characteristics of hydrothermal processes, stages of hydrothermalism, ages of deposition and others.

Although highly valuable, the information presented by Rodríguez Madrid et al. (2017), is focused on the general aspects of the auriferous occurrences of the area, and, as such, it does not help to explain the differences in types, sizes and grades of the deposits in the distinct rock types. These important differences, which reflect the way the hydrothermal fluids infiltrated the host rocks, and reacted with them, were successfully used by AUX to direct exploration and increase mineral resources.

The information presented here was gathered by the author while directing and supervising the geological activities of AUX, since the initial evaluation of the potential of the area.

\section{Geological setting}

In the northwest of Colombia, the Andes consist of accreted terranes brought in and elevated by the subduction of the Nazca and Caribbean Plates (Fig. 1A) (Aleman and Ramos 2000, Cardona 2003, Ramos 2010). Chibcha, or Chicamocha, is the largest and oldest of these terranes and forms the Central and Eastern Cordilleras, the Santander Massif, the Santa Marta mountain, the Perijás range, and, extending into Venezuela, the Merida Andes. To the west, it is flanked by the Piñon, Dagua and Choco terranes, part of which form the Western Cordillera.
Most of the northern portion of the Chibcha Terrane is formed by blocks of Precambrian rocks, Paleozoic sediments, and Jurassic and Cretaceous granitic intrusives (Gómez Tapias et al. 2006). Cediel et al. (2003) consider the Chicamocha terrane as Proterozoic and in fault contact with the Guiana Shield to the east.

The area is also tectonically affected by a colliding block from the northwest, the Panamá Indenter. The Nazca Plate, to the west, subducts at an angle of 30-40o, and the Caribbean Plate, to the north, subducts at 20-30o (Vargas and Mann 2013). According to these authors, the two plates continuously rub one another, eventually breaking off along a zone they named as the Caldas Tear (Fig. 1), separating the areas mostly affected by the Nazca Plate to the south and the Caribbean Plate to the north. The area of the proposed tear is marked by a large number of earthquakes.

There are a few important differences between the two sides of the tear. In the northern side, which overlays the Caribbean Plate, there are no volcanoes, and there are large masses of Precambrian rocks. This side is also characterized by intrusions of mafic-ultramafic complexes, amongst them the Cerro Matoso, at the north of Medellin, in Colombia, and Loma de Hierro, at the south of Caracas, in Venezuela (Fig. 1), both presenting large resources of lateritic nickel. Another effect of the upward push of the Caribbean Plate under the continent is the increasingly higher topography towards the north, with the highest peak of Colombia, at 5,700 meters, occurring in Precambrian rocks of the Santa Marta Mountain, next to the Caribbean Sea.

The interference zone of the two plates is marked by earthquakes, with two sites, named "nests", showing a higher concentration of them (Vargas and Mann 2013). One of the two nests occurs at Cauca, just south of the tear, and the other at Bucaramanga, to the northeast of the tear and along the lineament of the Merida Andes of Venezuela (Fig. 1).

As shown in Figure 1, the largest gold deposits of Colombia occur close and to the north of the Caldas Tear, near the earthquake nests. A large number of them are near Medellin, which is north of the Cauca nest, while those of the California District are at the north of the Bucaramanga nest. These two centers of mineralization overlay the deepest portions of the Caribbean Plate (Fig. 1B) (Taboada et al. 2000 and Bayona et al. 2012).

\section{Geology of the California and Vetas districts}

The California and the Vetas auriferous districts occur in the Santander Massif, which constitutes the northern part of the Chibcha terrane. It is a large peneplain uplifted to the elevation of around 4,000 meters above sea level, and presents a rough topography, marked by deep-incised northsouth valleys following crustal-scale faults. Additional faults to the northeast extend to the Merida Andes of Venezuela (Figs. 1 and 2). The two districts are located 35 kilometers, in a straight line, north of Bucaramanga.

The local geology is composed of the Bucaramanga Precambrian gneisses (Cediel et al. 2003), intruded by Mesozoic granitic rocks, and overlain by Cretaceous sediments (Gómez Tapias et al. 2006). In the California district (Fig. 2 and Table I) the gneisses are partially migmatized. The main granitic intrusives are Triassic and Jurassic, with smaller Miocene granitic masses also reported. Details of the 
granitic igneous rocks are presented by Cordani et al. 2005, Mantilla Figueroa et al. 2011, Mantilla Figueroa et al. 2012, Mantilla Figueroa et al. 2013 and Reyes and Sandoval 2013. The Cretaceous sediments, containing beds of limestones, sandstones, and shales, occur only at the western area of the auriferous district (Fig. 2).

The geological contacts shown on the map in Figure 2 are based on Royero and Vargas (1999) and Rodríguez Madrid et al. (2017), and on new field work information. Most of them are inferred. There are some inconsistencies in the geological map. For instance, there are small intrusives in areas shown as constituted by gneisses, and remnants of gneisses in areas presented as Jurassic intrusives. Areas with high values of radiometric potassium, identified by an airborne gamma-ray spectrometry survey conducted by AUX, are shown in the map, highlighting intrusives bodies (Fig. 2). Details of age

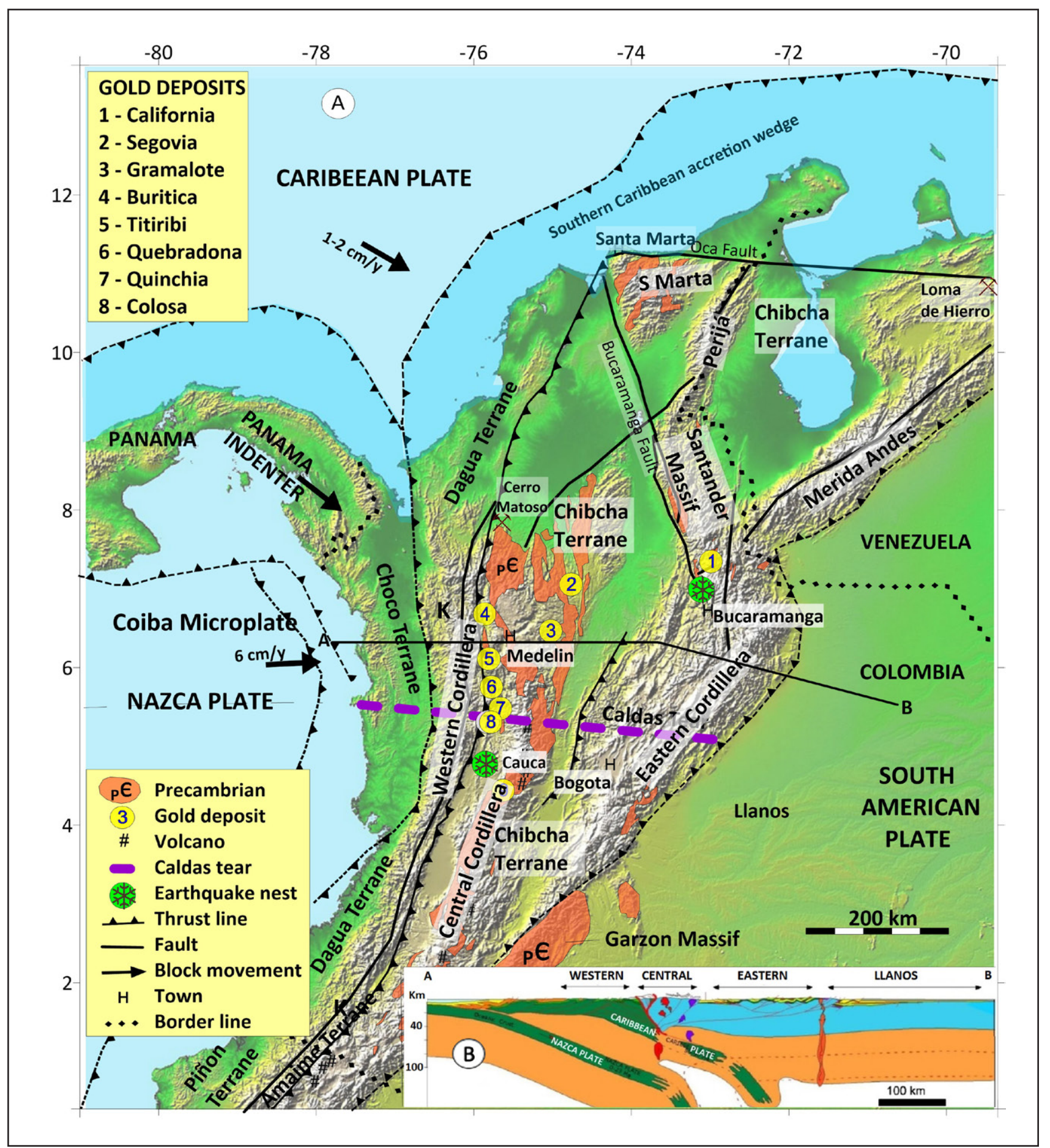

FIGURE 1. Map of Colombia showing the three Andean Cordilleras, made of accreted terranes, uplifted Precambrian rocks of the South American plate, and younger intrusives. The area is influenced by the Panama Indenter, and by the Nazca and Caribbean plates. The collision at depth of the two oceanic plates occurs approximately along the Caldas Tear (Vargas and Mann 2013), which marks the northern limit of the area with volcanoes in Colombia. Two earthquake nests occur to the South of large gold deposits. (Based on the geological map of Colombia, Taboada et al. 2000, Aleman and Ramos 2000, Pulido 2003, Ramos 2010, and other works). The area of the town of California (1) is located in the Santander Massif, at $7.35^{\circ} \mathrm{N}$ and $-2.95^{\circ} \mathrm{W}$. The inset (B) shows the two subducting plates along section A-B. 


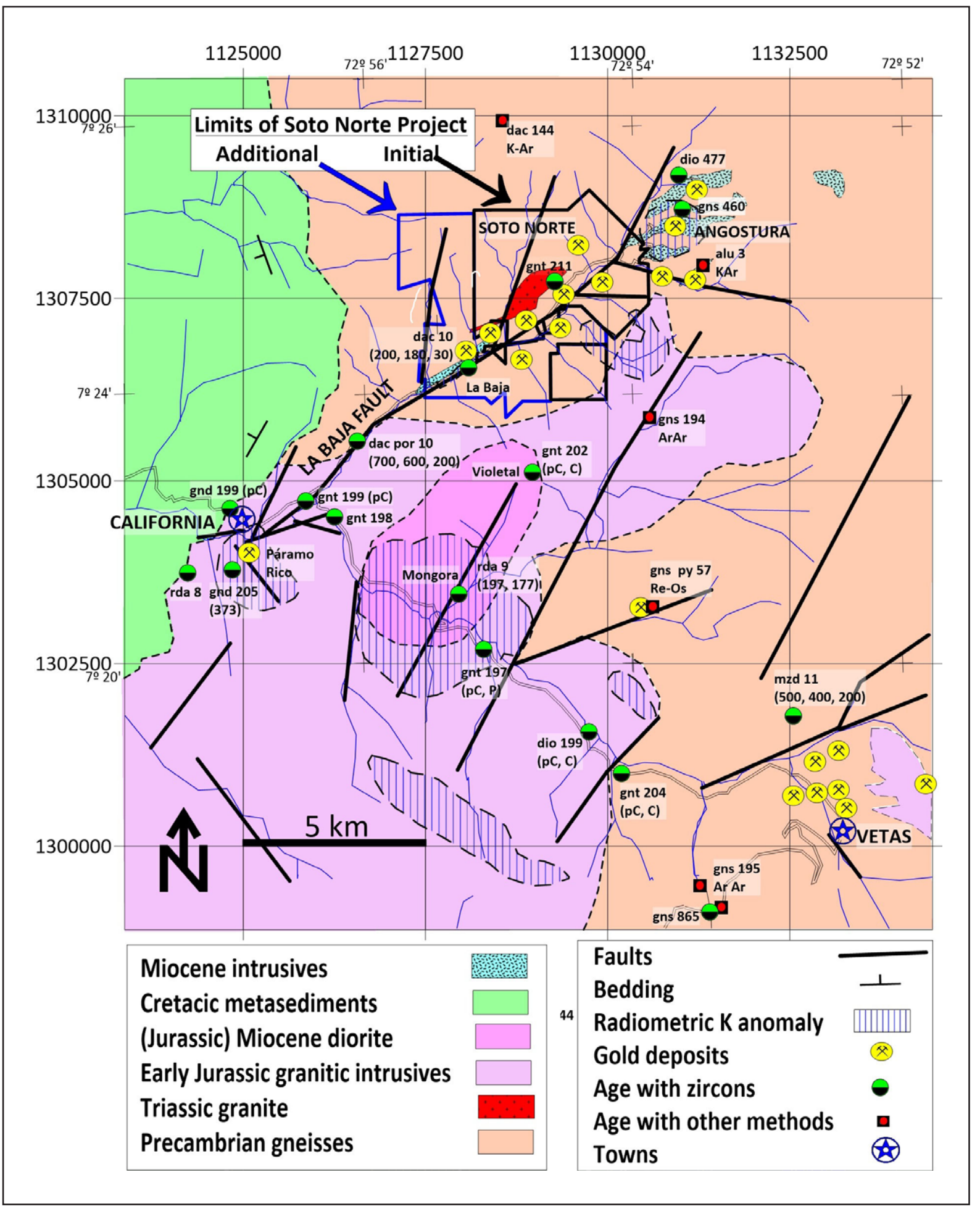

FIGURE 2. Geological map of California, showing the gold deposits of California and Vetas, and the limits of the Soto Norte Project. The mineralized area is composed of Precambrian gneisses and migmatites, with intrusions of Triassic/Jurassic and Miocene granitic rocks. Methodology and results of age determination were based on a catalog prepared by the Geological Survey of Colombia (Servicio Geológico Colombiano 2015). The ages are reported in millions of years. The abbreviations are: dac: dacite, dio: diorite, gns: gneiss, gnt: granite, gnd: granodiorite, mzo: monzonite; rda: rhyodacite, alu: alunite, py: pyrite, Ar: argon, K: potash, pC: Precambrian, C: Cambrian, and P: Permian.

determinations mentioned below are taken from a compilation made available by the Colombian Geological Survey (Servicio Geológico Colombiano 2015).

Lithological characteristics and isotopic dating reveal that the Bucaramanga gneisses, which consist of ortho and paragneisses, had their ages of crystallization and metamorphism reset by local migmatization and younger granitic intrusions. As an initial reference, outside of the California and Vetas district, the reported ages for the gneisses vary from 1,550 Ma to $864 \mathrm{Ma}$ (Cordani at al. 2005).

In the California and the Vetas districts, the gneisses yield younger LA-MC-ICP-MS U-Pb zircon ages. Geochronological data revealed ages varying from $865 \mathrm{Ma}$, from an outcrop South of Vetas (Cordani et al. 2005), to $460 \mathrm{Ma}$, from a gneiss 
TABLE 1. Stratigraphy at California

\begin{tabular}{l|l|l}
\hline Age & Unit & Lithologies, \\
\hline Miocene & Granitic intrusions & $\begin{array}{l}\text { Pié de Gallo quartz-monzonite } \\
\text { Angostura quartz-monzonite } \\
\text { other quartz-monzonites }\end{array}$ \\
\hline Jurassic & Metasedimentary rocks & quartzites, siltstones, limestones \\
\hline Jurassic / Triassic & Granitic intrusions & $\begin{array}{l}\text { El Cuatro granite }\left(^{*}\right) \\
\text { Móngora diorite } \\
\text { granites, diorites, granodiorites }\end{array}$ \\
\hline Precambrian & $\begin{array}{l}\text { Bucaramanga Gneiss } \\
\text { (partially migmatized) }\end{array}$ & $\begin{array}{l}\text { dark biotite gneiss } \\
\text { magnetite-hornblende gneiss } \\
\text { leucocratic gneiss } \\
\text { Aserradero paragneiss }\end{array}$ \\
\hline
\end{tabular}

$\left.{ }^{*}\right)$ Tentative position in table, as age is not clearly determined.

intruded by a diorite near Angostura (Mantilla Figueroa et al 2012). The intrusive diorite itself yielded ages of 477 and 482 $\mathrm{Ma}$, quite close to the age obtained from the intruded gneiss, suggesting a closer association. The geological context can be more complex, as the above-mentioned gneiss from near Vetas also yielded Ar-Ar age of 200 Ma on biotite. This $\sim 200$ Ma Ar-Ar age was also observed in two exposures of gneiss, 6.2 kilometers apart from each other, one at Vetas (195 Ma) and the other midway between Vetas and Angostura (194 Ma) (Cordani et al. 2005).

Additional geochronological data from the two districts suggest several episodes of remobilization and intrusions (Mantilla Figueroa et al. 2013). For instance, a small intrusion of monzodiorite located at North of Vetas revealed a LA-MCICP-MS U-Pb zircon age of $11 \mathrm{Ma}$, with inherited ages of 500 , 400 and $200 \mathrm{Ma}$ (Mantilla Figueroa et al. 2013).

The large area shown in Figure 2 as Early Jurassic granitic intrusives is constituted by several large granitic bodies, with their composition varying from granites to granodiorites, and to diorites. LA-MC-ICP-MS U-Pb dating of zircons of these intrusives yielded Late Triassic and Early Jurassic ages of 205 and $197 \mathrm{Ma}$, but also revealed inherited Precambrian, Permian, and Carboniferous ages (Dörr et al. 1995, Mantilla Figueroa et al. 2013).

To the West of California, Cretaceous metasediments appear as a succession of quartzites, metasiltstones, and marbles. They were deposited on a marine platform, and appear today with a steep dip to the west, away from the higher levels of the plateau to the east (Gómez Tapias et al. 2006, Royero and Vargas 1999, Rodríguez Madrid et al. 2017). Immediately to the west of California, one less competent siltstone unit appears highly deformed, with a chaotic folding suggestive of slump structures at the flank of a mountain. An age of $144 \mathrm{Ma}$ was obtained by K-Ar on hydrothermal sericite from a porphyritic dacitic intrusive found to the North of the project area (Sillitoe et al. 1982).

At Móngora, near the center of the Jurassic intrusions (Fig. 2), a porphyritic diorite, containing disseminations of chalcopyrite and pyrite, was explored for copper and gold, so far without attractive results. The porphyritic diorite was also outlined by the airborne gamma-ray spectrometry survey carried out by AUX. LA-MC-ICP-MS U-Pb zircon dating of one outcrop yielded the Miocene age of $9 \mathrm{Ma}$, with inherited Jurassic ages of 197 and $177 \mathrm{Ma}$ (Mantilla Figueroa et al. 2009).
Other Miocene intrusives occur in the valley of the La Baja River, lodged and elongated along the fault planes of the La Baja Fault Zone (Fig. 2). On a horizontal plane, the majority of them have a few hundreds of meters of thickness and up to one kilometer of extension. They are porphyritic granites, quartz-monzonites, and diorites, with ages ranging from 8 to $10 \mathrm{Ma}$, obtained by LA-MC-ICP-MS U-Pb zircon dating (Leal Mejía 2011, Mantilla Figueroa et al. 2009, Mantilla Figueroa et al. 2011). The Pié de Gallo quartz-monzonite, located in the lower left of the area, yielded a crystallization age of 10 $\mathrm{Ma}$, with inherited zircon grains of 200, 180 and 30 Ma (Leal Mejía 2011). These intrusives are contemporaneous with the 11 Ma monzodiorite to the north of Vetas, and with the $9 \mathrm{Ma}$ porphyritic diorite at Móngora. The 8-11 Ma period seems to be the last phase of magmatic activity in the area.

\section{The California auriferous corridor: characteristics and interpretations}

All gold deposits of the California district are rich in quartz and sulfides, occurring as veins in gneisses and disseminations, veinlets and minor veins in granitic intrusives. The majority and the largest of the deposits occur in a 6-kilometer-long corridor that follows the valley of the La Baja River, from 2 kilometers upstream of the town of California to the northern part of the Angostura deposit (Fig. 3). The river follows splays of the La Baja Fault, marks the center of the corridor, and is flanked by 700 - to 900 -meter-high steep slopes at its margins. Small tributaries follow incised valleys marking faults oblique to the La Baja Fault. The initial concessions explored by AUX covers 2.3 kilometers of the corridor downstream from Angostura, and contain the bulk of the resources already identified by the project. The adjacent concessions acquired in 2012 added 1.7 kilometers of the corridor. The geology of the area and the most important veins are shown in Figures 4 and 5.

\subsection{Geology of the California corridor and of the aurife- rous deposits}

The entire area of the project (Fig. 4) is dominated by gneisses and partially migmatized gneisses, intruded by small granitic bodies. The foliation of the gneisses strikes to the northeast, parallel to the La Baja fault, dipping at high angles to the northwest. In the area of the project, the La Baja Fault Zone follows the contact zone of a dark magnetite-hornblende gneiss to the northwest and a leucocratic quartz-feldspar gneiss to the southeast.

Small elongated stocks of granitic intrusions follow the fault strike and the foliation of the gneisses, presenting composition and textures similar or identical to those of the neosomes of the migmatized gneisses.

The magnetite-hornblende gneiss is medium grained and well foliated, consisting of hornblende, plagioclase, and quartz, always accompanied by biotite and magnetite, with the magnetite occurring as disseminations or small aggregates. Intercalations of hornblende amphibolites were identified in this unit (Appendix 1: A, B and C). Its mineralogical composition and homogeneity suggest a derivation from an igneous mafic rock. There are numerous patches with initial migmatization, marked by irregular masses of a leucocratic and pinkish neosome with coarse and pink subhedral porphyries of K-feldspar, in a mass of medium- to fine-grained 


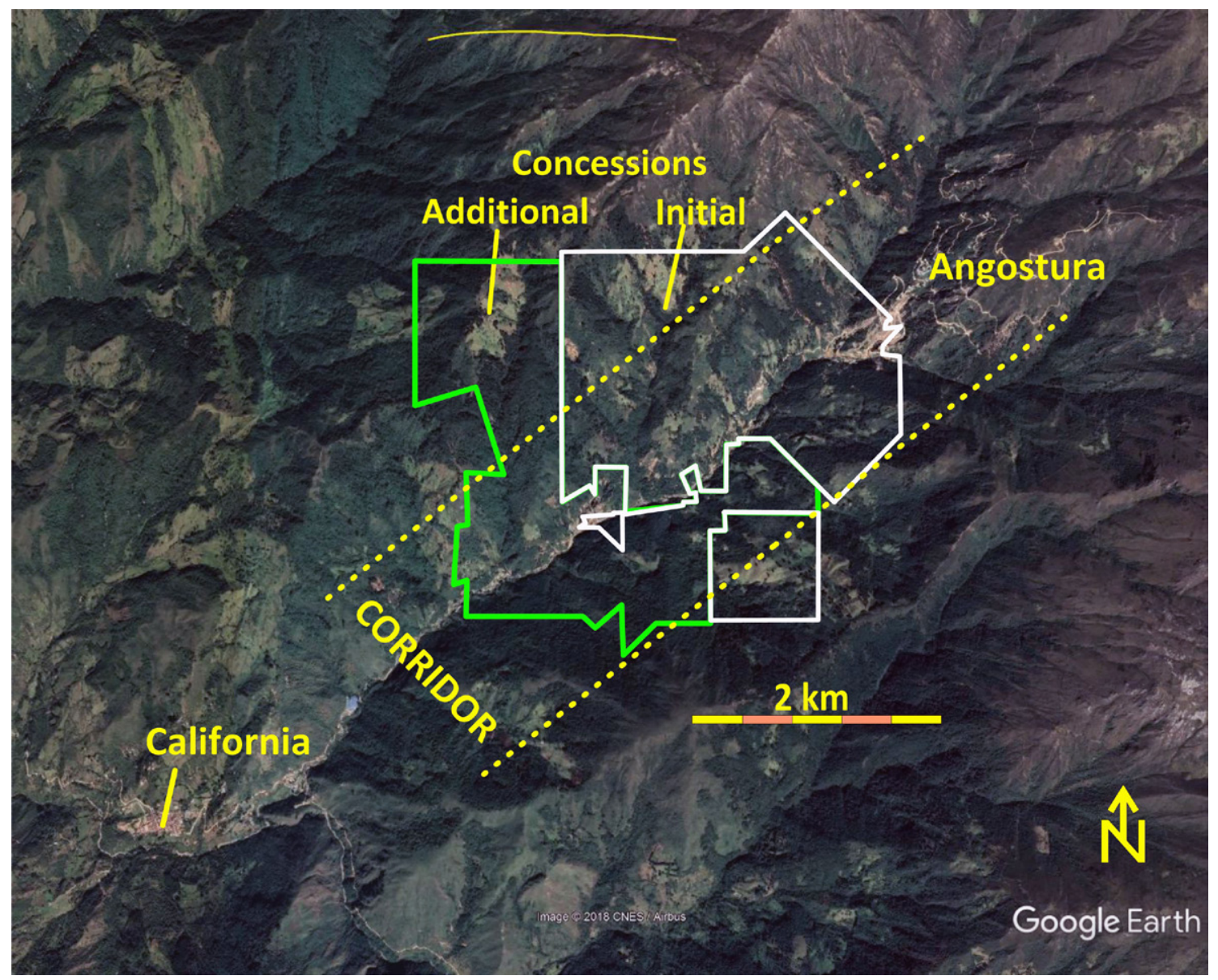

FIGURE 3. The auriferous gold corridor of California follows the La Baja River valley, from upstream of California to Angostura. The limits of the concessions of the Soto Norte Project are shown in this figure.

white plagioclase and quartz (Appendix 1: D and E). This gneiss hosts the most important auriferous veins of the area.

At El Cuatro, the El Cuatro granite (Fig.4, Appendix 1: F) occurs at the top of the mountain that flanks the San Juan Creek by the east and is very similar to the neosome of the magnetite-hornblende gneiss. This granite is light colored to pinkish, with large phenocrystals of pink K-feldspar and smaller plagioclase, embedded in a matrix of inequigranular plagioclase and quartz. It dips at a low angle to the southeast, towards the valley of the La Baja River, and is intensely brecciated at its basal 10 to 20 meters (Fig. 4, Appendix 5: $\mathrm{H})$. A similar body of this granitic intrusion occurs at the west of the San Juan Creek, in the form of a narrow and flat body dipping to the northwest, concordant with the foliation of the magnetite-hornblende gneiss.

At El Cuatro, a small dike of a macroscopically similar granite intruding magnetite-hornblende gneiss was intersected by hole LB-112, at the elevation of $2,500 \mathrm{~m}$. An age of 211 Ma was obtained for this dike by ID-TIMS (Isotope Dilution Thermal Ionization Mass Spectrometry) U-Pb on zircons (Mantilla Figueroa et al. 2013).

The leucocratic quartz-feldspar gneiss that occurs in the southern side of the La Baja fault (Appendix 1: G) is a monotonous rock composed of medium grain size quartz and white feldspars, with flakes of muscovite defining the foliation. Chlorite is usually present and sulfide minerals are scarce and disseminated. The migmatized portions show a neosome with an igneous texture, consisting mostly of medium-grained white feldspars and quartz, with only a few coarse-grained feldspars (Appendix 1: $\mathrm{H}$ ).

Miocene intrusives, like those of Angostura and Pié de Gallo, varying in size from small dikes to masses with tens of meters of thickness and hundreds of meters of length, follow the fault zone and intrudes both gneisses (Fig. 4). They are light colored and quartz-monzonitic in composition, showing porphyritic to equigranular textures (Appendix 1: I and J). They were described as alaskites or leucogranites by Mantilla Figueroa et al. (2011), and are composed by quartz and feldspars, with less than $5 \%$ of mafic minerals and very little of muscovite.

At La Rosa, at the right-hand side of Figure 4, on the hanging-wall side of the magnetite-hornblende gneiss, there is a dark biotite gneiss with a variable percentage of biotite, quartz and white feldspars, and without magnetite and hornblende (Appendix 1: K). It is well foliated and homogeneous, without banding or indication of former layering. In the migmatized portions, the neosome is similar to that of the magnetitehornblende gneiss.

At Aserradero, at right-lower side of Figure 4, on the footwall side of the leucocratic quartz-feldspar gneiss, there is a welllayered gneissic sequence, with the individual layers showing different mineral compositions, as quartz-feldspar-muscovite, epidote-chlorite-amphibole-quartz-feldspar, biotite-feldsparquartz and others. Their grain size varies from fine to coarse, and occasionally the rock is pebbly or brecciated. The variation in composition and granulometry of the layers suggests that they 
derive from a succession of impure arenites, siltstones, pelites and arkoses. These layers also show initial migmatization, with the neosome containing porphyries of pink K-feldspar, similar to those observed in the magnetite-hornblende gneiss and in the dark biotite gneisses. (Appendix 1: L).

\subsection{Structures}

The La Baja Fault Zone is formed by a tens of meters wide swarm of faults striking to the northeast, nearly concordant with the foliation of the gneisses (Fig. 4). In the initial area of the Soto Norte Project, the zone closely follows the contact between the magnetite-hornblende gneiss and the leucocratic quartz-feldspar gneiss, suggesting that the differences in competence of these two units were important for the location of the fault. At Angostura, at the northeast of the project area, the fault zone is somewhat unclear, possibly due to the quartzmonzonite intrusives in the area.

On both sides of the fault zone, there are tension fractures and faults striking northwest and dipping to the northeast. Geological mapping and drilling showed that these structures are more common in the leucocratic quartz-feldspar gneisses and are frequently filled by quartz veins. This observation suggests that this rock is more rigid than the magnetitehornblende gneiss.

There are also thrust faults, such as the San Juan Fault, with upthrow of the block at the east over the block at the west. As a consequence of that thrust, and the dip of the gneisses, to the southwest of the San Juan Fault, the main faults of the La Baja Fault zone occur in the magnetite-hornblende

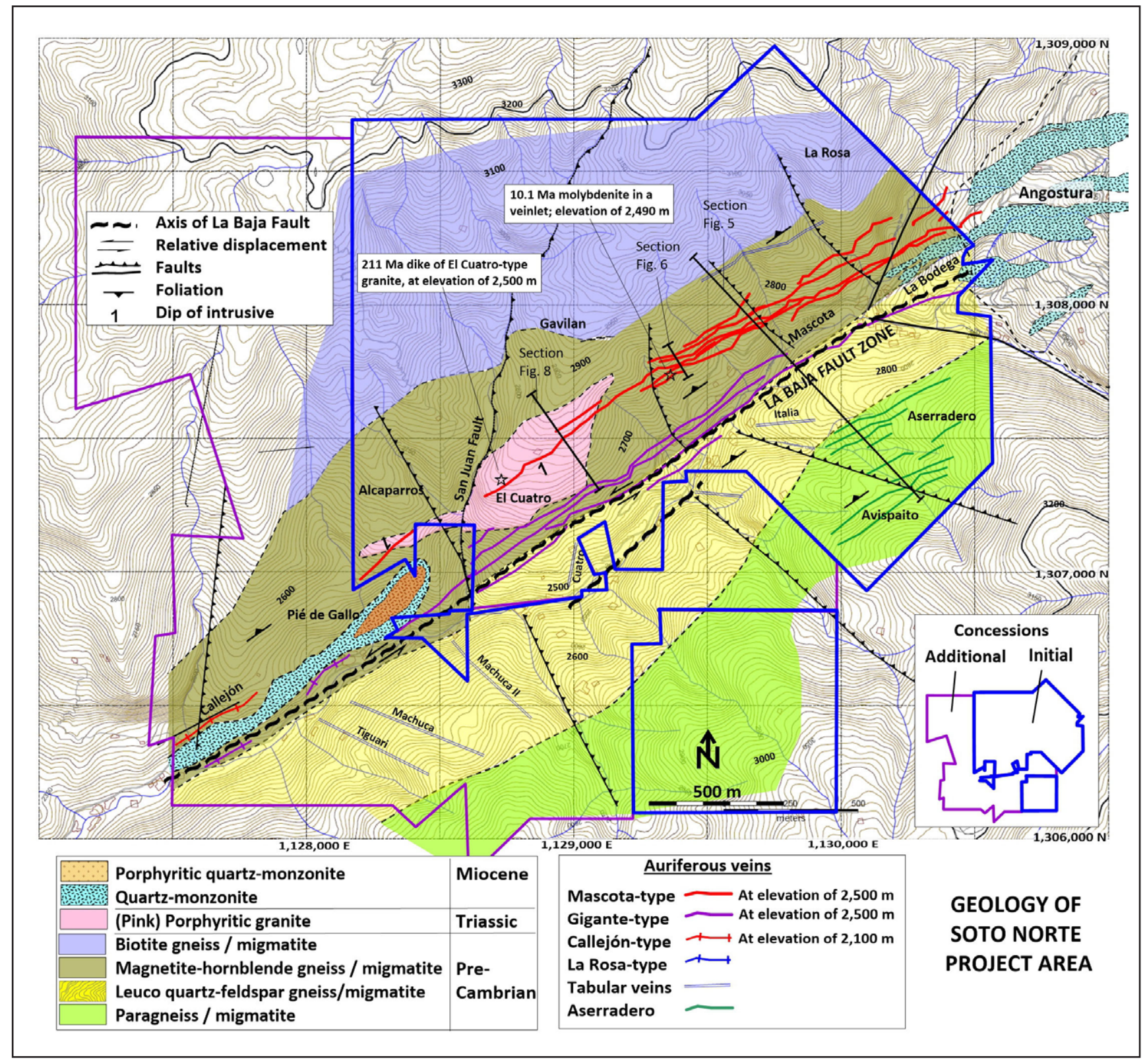

FIGURE 4. Geology of the area of the Soto Norte Project, initial and additional concessions. The gneisses dip to the northwest. The most important veins are the Mascota-type veins, occurring only in the magnetite-hornblende gneiss, and the Gigante-type veins, occurring in splays of the La Baja Fault. These two types of veins are shown as they occur at the elevation of 2,500 meters, below the level of the La Baja River. Other veins, as Machuca, Tiguari and Italia, are shown as they occur near the surface. The map also shows the locations of the geologic sections of Figs. 5, 6 and 8, as well as the sites of the molybdenite and granite samples collected by Rodríguez Madrid et al. (2017) for age determination. 


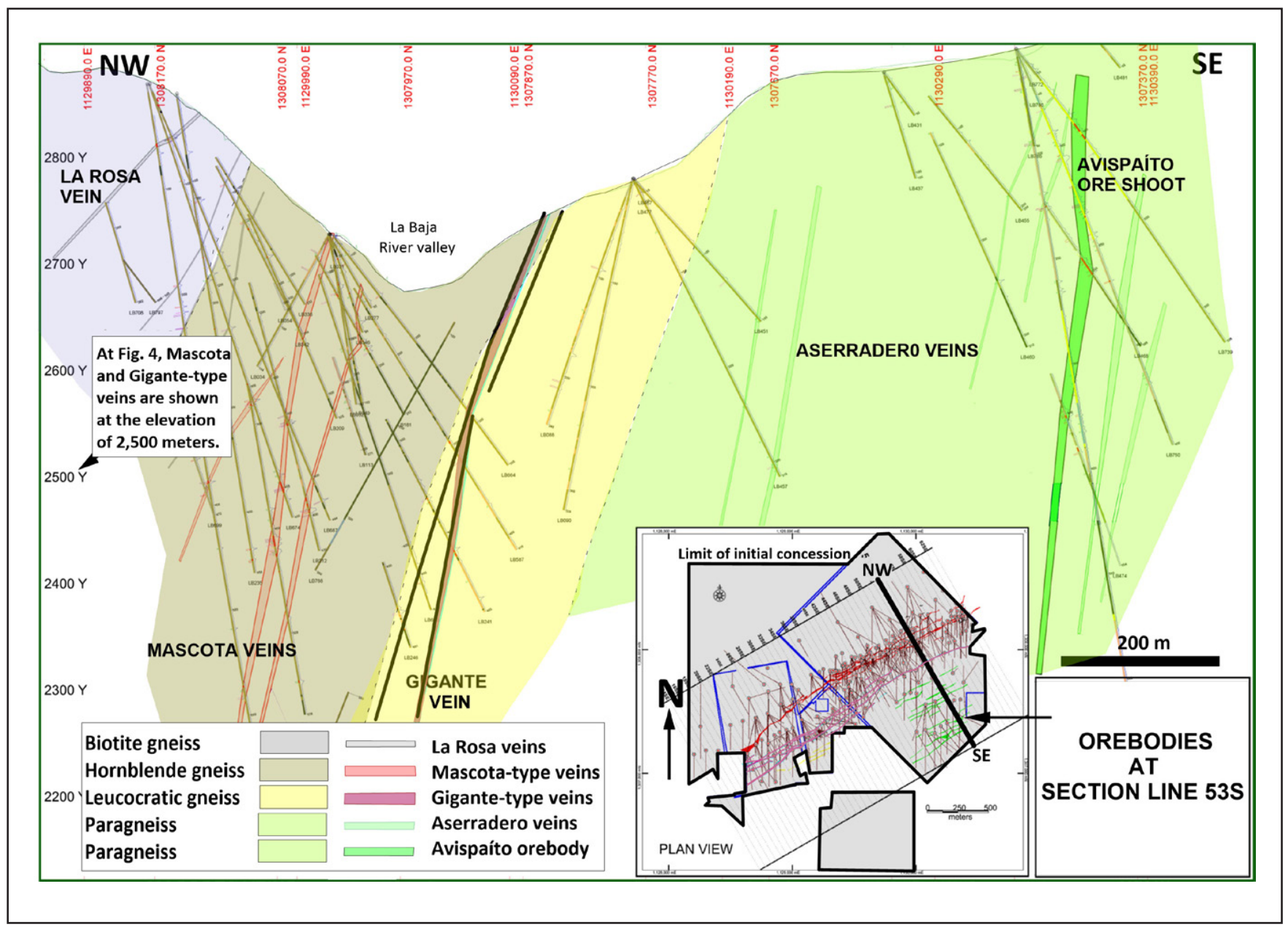

FIGURE 5. The relationship of the veins with the gneisses is shown as seen in the geological section 53S. The La Baja Fault Zone follows close to the contact between the two central gneisses, and the important veins of the Mascota-type occur only in the magnetite-hornblende gneisses on the hanging-wall side of the fault. The Gigante-type veins, the next in importance, occur in fault planes of the La Baja Fault Zone. The La Rosa veins were only observed at shallow depths. In this section, tabular veins were only seen in the Aserradero paragneiss, which also has the Avispaíto brecciated ore shoot.

gneiss, not far from its contact with the leucocratic quartzfeldspar gneiss.

Minor faults parallel to the foliation of the gneisses and to the main fault planes of the La Baja Fault Zone were observed in drill cores from Aserradero, La Rosa, Gavilán and other sites.

\subsection{Mineralization styles and mineral composition}

The origin, type and mineralogy of the gold deposits at the California auriferous corridor (e.g. disseminations, veinlets and small to large veins) depend mainly on the mineralogical and textural composition of the host lithologies, which determine their receptivity and capability to receive and react with hydrothermal fluids. In addition to the lithological controls, some deposits were also favored by repeated and superimposed events of tectonism and hydrothermalism.

All deposits are sulfide-rich and associated with zones of microcrystalline silica, with the gold being accompanied by silver, copper, and tellurium. They are geochemically marked by local buildups of arsenic, antimony, iron, lead, manganese, mercury, molybdenum, sulfur, uranium, tungsten and zinc, in concentrations and distributions that vary from one deposit to another. The gold occurs in a free form, as electrum and tellurides, often in particles of 4 to 15 microns. It is commonly found next to pyrite and quartz, as inclusions, or filling microfractures in pyrite. The most common sulfides associated with gold are pyrite and chalcopyrite, followed by covellite, enargite, bornite, tetrahedrite, molybdenite, galena, sphalerite, huebnerite, wolframite, and others. Most of the veins become poorer in gold and richer in silver towards the surface, accompanying an upwards decrease of the silicification and an increased argillization of the host gneisses.

The depth of oxidation of the sulfides along fractures varies from a few to near 100 meters, depending on the intensity of fracturing and the resistance of the rock minerals to oxidation. In general, silicified zones are more resistant to weathering and protect the sulfides from oxidation.

\subsection{Stages of mineral deposition}

The work of Rodríguez Madrid et al. (2017) on drill cores obtained by Ventana presents a good description of the ore minerals, and of their order of deposition. Here we present a summary of their main observations, and a suggestion to the readers interested in additional details to look at their work.

Rodríguez Madrid et al. (2017) identified six stages of hydrothermal alteration in the area. The first stage comprised 
propylitization, with epidote, chlorite, isolated calcite, veinlets of specularite, and minor pyrite and chalcopyrite. They believe that this stage may be contemporaneous with or younger than a molybdenite-bearing veinlet cutting a dike of the El Cuatro granite crossing the magnetite-hornblende gneiss (hole LB269, 270 meters). The Re-Os dating of molybdenite yielded an age of $10.14 \mathrm{Ma}$.

Stage 2 involved phyllic alteration, with sericite-illite, quartz and pyrite, accompanied by quartz veins with pyrite. Some gold mineralization occurred during this stage. 40Ar/39Ar dating of sericite formed during this stage yielded an age of approximately 3.4 Ma (Rodríguez Madrid et al. 2017).

Stages 3 to 6 occurred during superposed pulses of brecciation, are marked by alunitization and silicification. These alterations were accompanied by the deposition of pyrite and most of the gold-silver mineralization. Stage 3 is marked by copper sulfides (bornite, covellite, and chalcopyrite), stage 4 by wolframite, stage 5 by enargite, and stage 6 by sphalerite. 40Ar/39Ar dating of alunite yielded ages between 2.6 and 1.6 Ma for these four stages (Rodríguez Madrid et al. 2017). A slightly older age of $3.4 \mathrm{Ma}$, obtained by K-Ar dating, was interpreted as the age of the Angostura deposit (Leal Mejía 2011).

There is a suggestion that the mineralization occurred after the La Baja Valley was already present in the area, and, therefore, affecting it (Bissig et al. 2015, and Rodríguez Madrid et al. 2017).

Present-day up flowing sulfidic, acid, saline hydrothermal waters are indicated by the continuous surge of hot water with a strong smell of sulfuric acid from holes drilled by AUX near the limit with the Angostura concession. It corroded steel parts used to protect the collar of the holes.

\section{The gold bearing vein-types of the Soto Norte project}

The largest gold deposits in the area of the Soto Norte Project are veins in gneisses, varying in size and grade according to the mineralogy, structure and competence of the host gneiss (Figs. 4 and 5). The largest, richest and most important veins are the Mascota type, found only within the magnetite-hornblende gneiss, followed by the Gigante veins, that are found in the fault zone, either in magnetite-hornblende gneiss or in the leucocratic quartz-feldspar gneiss. Veins in the Aserradero para-gneiss and in the dark biotite gneiss come up in sequence.

\subsection{The Mascota-type veins}

The Mascota-type veins, the largest and richest of the district, constitute more than $50 \%$ of the identified resources of the Soto Norte project. The most important of them, the Mascota, extends continuously for 2 kilometers, from the Angostura intrusion, at the Northeast, to the San Juan Fault, at the Southwest, being flanked by other similar veins (Fig. 4). The image in Figure 4 shows the veins as they were found at the elevation of 2,500 meters. Each one occurs inside a tabular and silicified band of gneiss, which appears in a wide envelope of chloritization and alunitization. The bands of silicification are roughly concordant to the foliation of the magnetite-hornblende gneiss, varying in thickness from a few decimeters to tens of meters, and are continuous on depth and on strike from hundreds of meters to more than one kilometer. Commonly they present remnants of chlorite replacing hornblende and outlining the trace of the former foliation of the gneiss (Appendix 2: A and B). These lines would represent zones of less resistance of the rock to brecciation. Masses of alunite replacing feldspars and being replaced by silica (Appendix 2: $\mathrm{C}$ and $\mathrm{D}$ ). The later also shows cavities produced by the leaching of remnants of alunite in a silicified zone.

The bulk of the gold mineralization is localized in breccias and cavities that occur inside and sub-parallel to the zones of silicification. The clasts of the breccia are made of very angular fragments of the fine-grained silica that form the silicified band (Appendix 3: A). Quite often, there are clasts of the breccia itself, indicating repeated periods of fracturing and brecciation (Appendix 3: B). The clasts are of different sizes, never rounded, and are cemented by fine-grained silica, quite often accompanied by sulfides. Open spaces are filled by finegrained silica and sulfides, not rarely deposited in sequence (Appendix 3: C). In the mineralized zone, the walls of any open space left are covered by a layer of small quartz crystals, usually auriferous. For details on the sulfides, their form of occurrence and order of deposition, we refer the reader to look for the article of Rodríguez Madrid et al. (2017).

The breccia, and the mineralization, appear in the more silicified bands and extends internally to them for hundreds of meters along their depth and strike extensions. The thicker zones of silicification might show more than one zone of mineralized breccia, and a mineable vein might contain more than one level of mineralized breccia. Combining several zones of breccia, an individual mineable vein would vary from a few meters to more than 20 meters, with average gold grades above $3 \mathrm{~g} / \mathrm{t}$.

Most of the gold is free, observed in faces and fractures of quartz and iron-bearing sulfides. Very little gold is found outside the breccias. In general, the gold is accompanied by variable percentages of silver, copper, iron, sulfur, arsenic, mercury, antimony, lead, zinc, tellurium, tungsten, manganese, uranium, molybdenum and other elements. The concentrations of these elements vary from breccia to breccia, and that difference is used for geological correlation between the breccias intercepted in the core holes.

Towards their upper parts, the veins slowly become poorer in gold and richer in silver (Figs. 6, 7 and 8). The decrease in gold grade is accompanied by a reduction in the chloritization and an increase in argillization and alunitization of the host gneisses.

\subsubsection{Feeder zones of the Mascota-type veins}

In 2012, an unexpected mineralization was found in hole LB-623, drilled with an inclination of 800 to the southeast, for deeper intersections of Mascota-type veins (Fig. 6). For 238 meters along its course, the hole progressed inside a swarm of branching and mineralized tension fractures, parallel to the hole and oblique to the foliation of the gneiss and to the Mascota-type veins (Fig. 6). Although sub-parallel among themselves, these fractures are quite irregular in shape and continuity, and are characterized by silicification of their walls, and open spaces with quartz and auriferous sulfides (Appendix 3: D)

The gold mineralization was of high-grade, and the assay of the combined cores of the entire 238-meter interval 


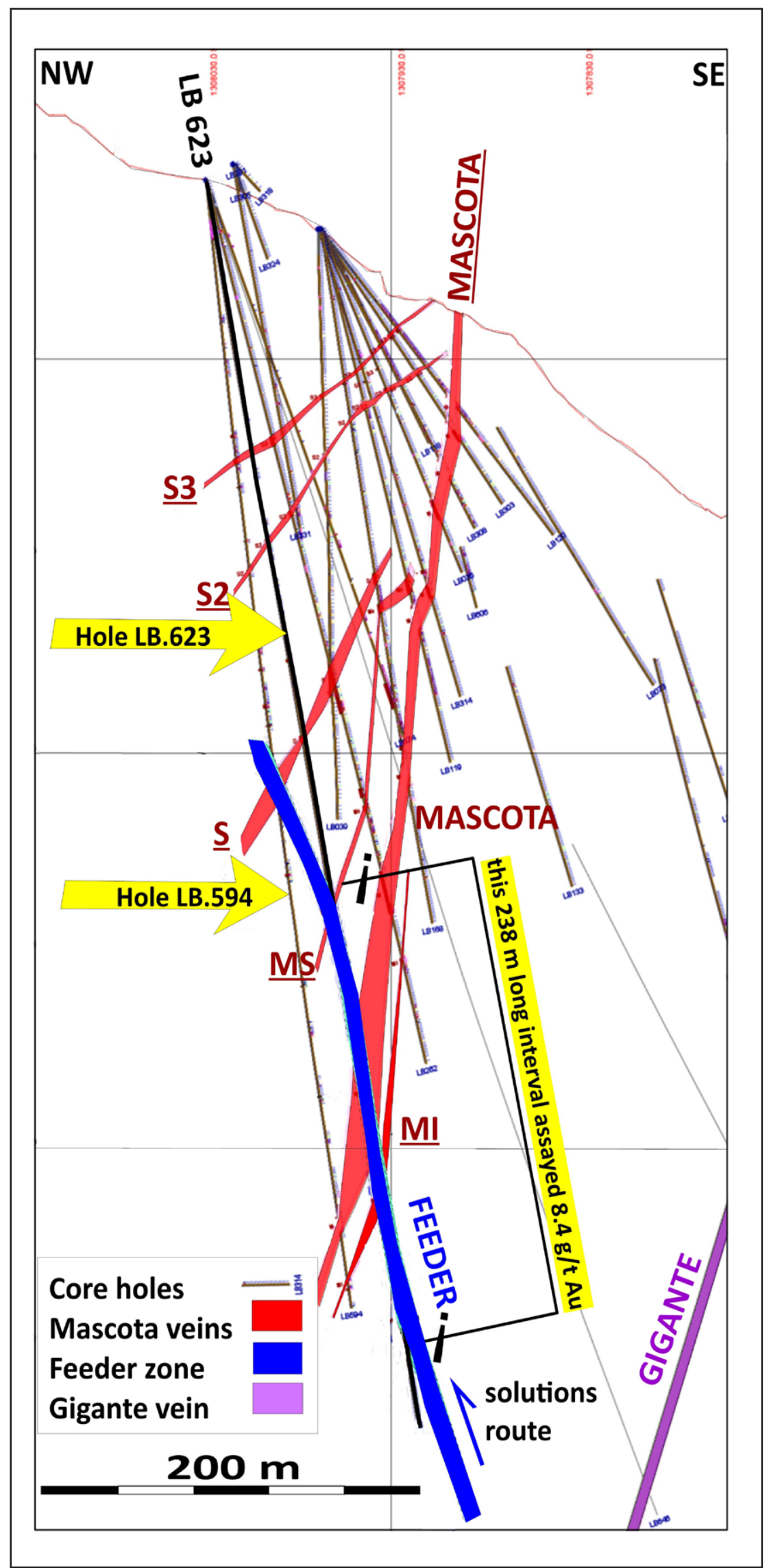

FIGURE 6. Designed to intercept the Mascota-type veins at depth, the hole LB.623 penetrated 238 meters of a swarm of small irregular tension fractures, which are sub-parallel to the hole, partially silicified, auriferous, and rich in sulfides. The average grade for these $238 \mathrm{~meters} \mathrm{is} 8.4 \mathrm{~g} / \mathrm{t}$ $\mathrm{Au}$. Above that interception, the zone was also cored by hole LB.594. This zone of fractures was the pathway used by "pregnant" hydrothermal fluids to reach and penetrate the hornblende gneiss and to mineralize it with the Mascota-type veins, the Mascota, MI, MS, S, S2 and S3. A Gigante-type vein, shown at the lower right of the figure, have been intercepted by another hole. 


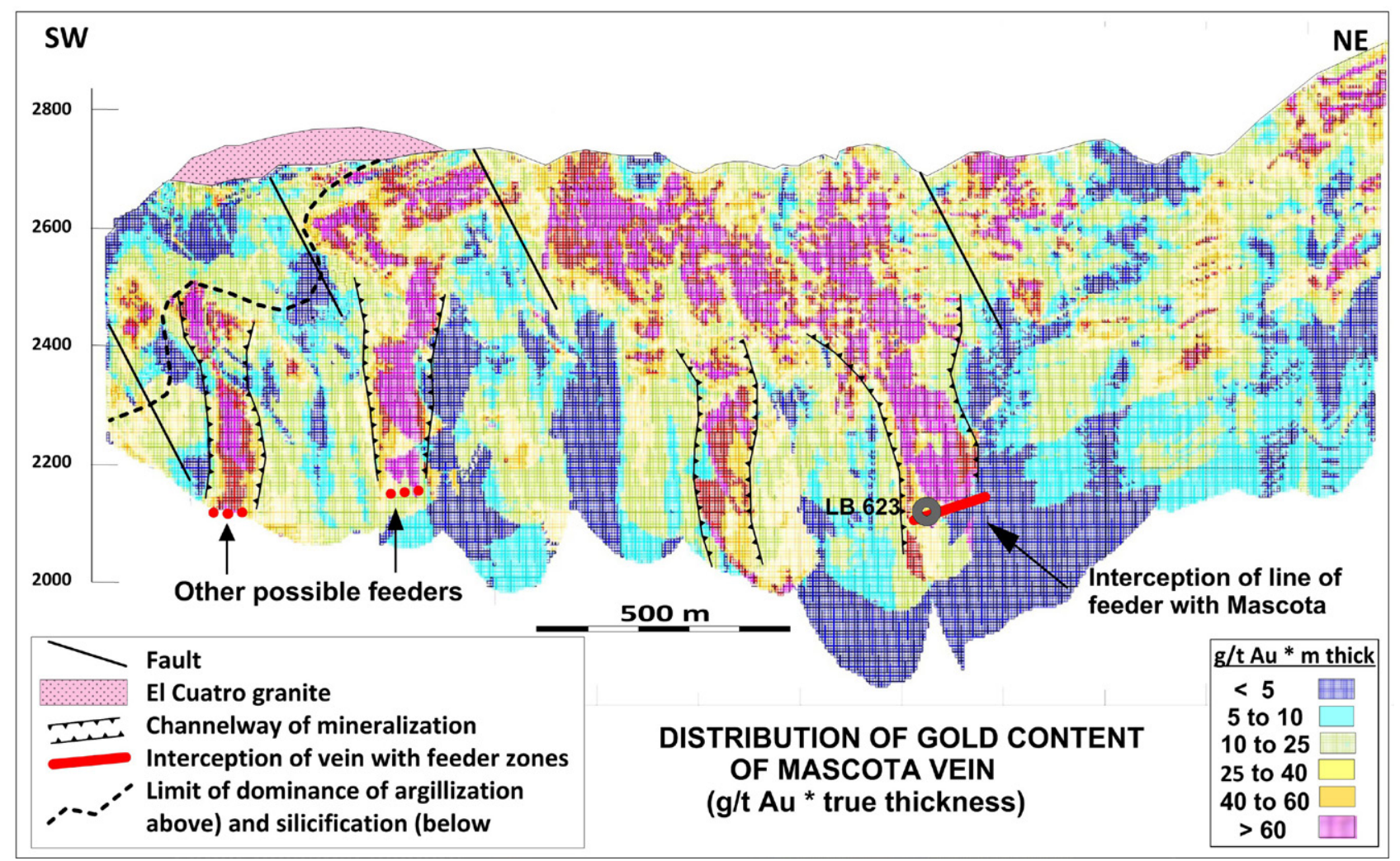

FIGURE 7. The distribution of the gold (grade of gold, in g/t, multiplied by local true thickness) of the main Mascota-type vein is shown in this longitudinal view of the vein. The interception of the vein with hole LB.623 is shown at the lower right of the center. The lateral extension of the interception (red line) was verified by subsequent holes. The concentration of the higher values of gold in a vertical zone just above the point of interception clearly indicates the main route followed by the ascending fluids. Similar accumulations of gold were observed at the southwest of the area, suggesting other feeder zones. In the southwestern part the section, particularly below the flat-lying El Cuatro granite, the transition of argillization (above) to silicification (below) occurs at greater depths, with the higher gold content being limited to the more silicified zone (see Figs. 8 and 11).

averaged $8.4 \mathrm{~g} / \mathrm{t} \mathrm{Au}$. Subsequent holes drilled in this area revealed that the swarm of mineralized fractures has about 20 meters of true thickness and continues in depth towards the La Baja Fault Zone, at the southeast.

A longitudinal section of the Mascota vein showing the distribution of its contained gold (grades of gold multiplied by the true thickness of the vein), as observed in drill cores, shows a gold enrichment immediately above the interception of hole LB-623, and extending upwards from this position (Fig. 7). This same section also indicates that there are similar bulges of mineralization to the southwest of this one. Clearly, these mineralized fractures constituted channels through which rising hydrothermal fluids left the fault zone, and moved up into open cavities in the hornblende gneiss, altering and mineralizing it with the Mascota-type veins.

\subsection{Gigante-type veins (mineralization in the La Baja fault planes)}

The Gigante-type veins are the second most important ore occurrences of the project, representing about onethird of the estimated resources. They are characterized by concentrations of auriferous quartz and sulfides in fault planes of the La Baja Fault Zone (Fig. 4, presents them as they occur at the elevation of 2,500 meters). The veins occur at the two gneisses' contact zone, following the fault strike, being more frequent in the leucocratic quartz-feldspar gneiss and associated felsic granitic intrusives. To the southwest of the San Juan Fault, in the additional concessions, they also occur in magnetite-hornblende gneiss.

The individual veins are composed of sets of branching planes of fault, marked by mylonitization, chloritization, sericitization, silicification, and sulfidation, with variable concentrations of rounded masses of silica, and visible masses of sulfides (Appendix 4: A, B, and C). The total thickness of the mineralized set of planes may reach several meters. The hydrothermal alteration of the host rocks is usually limited to a narrow zone of chloritization along the margins of the mineralization.

At the northeastern limit of the concessions, near Angostura, fault planes are more frequent; the hydrothermal alteration affects a larger area, and the mineralization occurs mainly in leucocratic gneiss, as disseminations and narrow veinlets (Appendix 5: A, B and C).

\subsection{Tabular quartz veins}

There are several tabular quartz veins in the leucocratic quartz-feldspar gneiss that occurs at the southeastern side of the La Baja Fault Zone (Fig. 4 and Appendix 5: D and E). These veins fill straight tension faults and fractures oriented east-southeast, in en echelon structures related to the La Baja Fault. Some of them (e.g. Machuca, Italia and Tiguari, Fig. 4) are more than 100 meters long and 1-2 meters wide. They 
consist of massive or banded quartz, with disseminations of sulfides, mostly pyrite.

Tabular veins also occur in the other gneisses. Those in the magnetite-hornblende gneiss are small, and limited to secondary faults near the La Baja Fault. Those in the Aserradero paragneiss follow fault planes parallel to the La Baja Fault, are continuous for hundreds of meters, and have grades of a few grams of gold per ton.

\subsection{Avispaíto ore shoot (mineralized breccia in the Aserradero gneiss)}

At the eastern limit of the initial concessions, in a biotite paragneiss, there is a 20 meters wide breccia impregnated by fine-grained auriferous pyrite and chalcopyrite, and surrounded by an envelope of chloritic alteration (Fig. 5 and Appendix 5: F). This breccia plunges to the southwest and is the result of a complex structure of folding and faulting. Although gold grades are lower than those of Mascota and Gigante veins, the prospect for underground mining is favorable and it deserves further study.

\subsection{La Rosa veins - (mineralization in the dark biotite gneiss)}

The dark biotite gneiss that occurs on the hanging-wall side of the magnetite-hornblende gneiss was core drilled when the drill rigs were moved up the mountain, to reach the Mascota and Gigante veins at greater depths. While drilling these gneisses, the cores revealed tens of meters wide sections with intense argillization, and alunitization of plagioclase, accompanied by weak disseminations and veinlets of silica containing auriferous pyrite and copper sulfides. The alteration and mineralization resemble Stage 1 and 2 of the hydrothermal alteration of the area (Rodríguez Madrid et al. 2017). The altered zones are parallel to the foliation of the gneiss and seem to constitute the apical part of another group, or another type of veins. It is quite reasonable to expect that gold grades will increase with depth.

\subsection{Mineralization in the granitic intrusives}

At El Cuatro, the gold-poor apical portion of the Mascotatype veins reached the brecciated base of the overlying and inclined body of the El Cuatro porphyritic granite (Fig. 8). At the surface, the mineralization is indicated by veinlets oriented exactly parallel to the Mascota-type veins that appear in the underlying gneisses. The bulk of the mineralization is made by sulfide impregnation of the brecciated base of the granite (Appendix 5: G, and $\mathrm{H}$ ). The mineralizing fluids flowed inside the breccia, down-slope from the intersections with the veins (Fig. 8 ), forming a deposit with more than 20,000 tons of contained silver, plus copper. The "downhill" shape of the mineralization supports the suggestion that the La Baja valley was already present when the mineralization occurred (Bissig et al. 2015).

The quartz-monzonitic intrusives occurring in the corridor of the La Baja Fault Zone present variable degrees of argillization, sericitization, silicification, sulfidation and auriferous quartz. The mineralization occurs as short veins, veinlets and disseminations of silica, with sulfides (pyrite, chalcopyrite, molybdenite, covellite, tetrahedrite, enargite, sphalerite, galena and others). It is more intense at Angostura
(Godoy et al. 2012), just outside the northern limits of the Soto Norte Project area, where it appears in a group of close-by intrusions, and at Pié de Gallo, in the concessions acquired from Galway and Calvista (Fig. 4). The aerial geophysical survey revealed a uranium anomaly over the Pié de Gallo intrusive, correlating well to a small vein containing uraninite and autunite associated with alunite, explored with a drive in the fifties (Bueno 1955, Pagnacco 1962, Ward et al. 1970).

\section{Discussion}

\subsection{Model for gold mineralization hosted in gneiss}

The model here presented (Fig. 9) represents the state of the art when the project was transferred from AUX to Mubadala. It considers that the mineralizing fluids rose along fault planes of the La Baja Fault Zone, altering the gneisses and migmatites along the route, and precipitating the hydrothermal minerals where favorable conditions were present. It seems natural to assume that the first deposits to be formed were of the Gigante-type veins, in the fault zone itself, marked by mylonitization and narrow hydrothermal alteration along the margins of the veins.

Flowing laterally into open fractures and faults oblique to the main fault zone, the fluids penetrated the lithologies affected by the La Baja Fault Zone, reacted with them and formed deposits of distinct types, grades and sizes, depending on the mineralogy of the host gneiss and on the local structure.

Located in the hanging wall side of the fault zone, the most chemically reactive rock of the area, the magnesium- and ironrich magnetite-hornblende gneiss, was in a very favorable position to receive the mineralization. Along certain planes of its foliation that probably were opened by tension stresses, the rock was sequentially argillized, chloritized, alunitized and, very important, heavily silicified. Under accumulated tension stress, the silicified bands eventually broke down along internal planes of weakness, and were brecciated, resulting in ideal conditions for the formation of the sulfide mineralization of the Mascota-type veins.

Next to the magnetite-hornblende gneiss, still on the hanging wall side, the dark biotite gneiss was also hydrothermally altered along the planes of foliation. So far, only the upper portions of these veins have been drilled and their mineral potential remains opened (Fig. 9).

On the footwall side of the La Baja Fault Zone, the mineralization in the competent leucocratic quartz-feldspar gneiss is limited to subvertical tension fractures oblique to the fault, which host the tabular straight and long veins of auriferous quartz.

The individual layers of the Aserradero gneiss differ in competence and degree of reactiveness, some being similar to the magnetite-hornblende gneiss, other to the leucocratic quartz-feldspar gneisses. They host flat tabular veins, but with low grades of gold. The best mineralization identified in these gneisses is represented by the Avispaito breccia.

\subsection{Criteria for vein definition during resource estimation}

Although the veins present significant variation in thickness and grades along their strike and dip, it is always important for the mining to have the limits of their economically mineable 


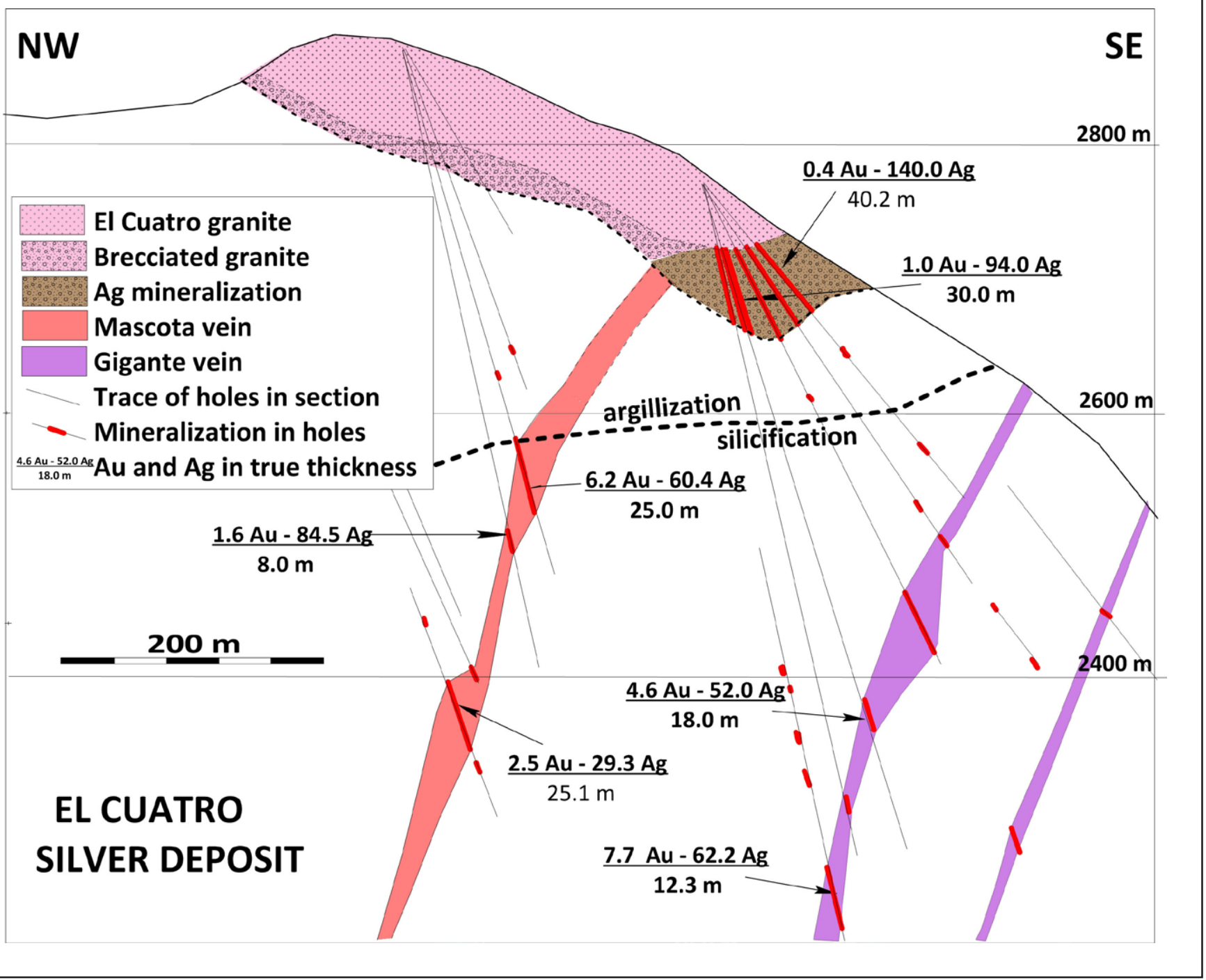

FIGURE 8. At El Cuatro, immediately below the El Cuatro granite, the Mascota-type mineralization is characterized by argillization and weak silicification, with low gold grades and an increase in silver. When the ascending hydrothermal fluids reached the brecciated base of the granite, they followed the breccia downhill, and deposited the sulfides between the clasts, forming a silver orebody. In the best holes, the grades ranged from $94 \mathrm{~g} / \mathrm{t} \mathrm{Ag} \mathrm{over} 30$ meters to $140 \mathrm{~g} / \mathrm{t} \mathrm{Ag}$ over 40 meters.

areas defined with a good degree of precision. To obtain the highest level of reliability, the following procedure was applied by AUX during the exploration work.

1. The definition of the limits of economic mineralization in a core hole was the responsibility of two trained geologists, one who logged the hole and the other who integrated the incoming information.

2. Together, they examined the geological cross-section and a graphic log of the hole, focusing on the mineralogical, structural, and textural characteristics of the cored veins, and compared these characteristics with those of the same veins in adjacent holes. For this, they used logs and photographs of the cores of the holes taken before and after saw sampling.

3. They examined the distribution and grades of the economic elements, $\mathrm{Au}, \mathrm{Cu}$, and $\mathrm{Ag}$, and of the indicator elements in the hole and adjacent holes. As indicators, they used $\mathrm{Fe}, \mathrm{S}, \mathrm{As}$, $\mathrm{Hg}, \mathrm{Sb}, \mathrm{Pb}, \mathrm{Zn}, \mathrm{Te}, \mathrm{W}, \mathrm{Mn}, \mathrm{U}$, and Mo. Individual veins used to have a particular range of values of these elements.

4. Together, they established the limits of the veins, which were used to prepare the 3D modeling for ore resource estimates. Comparing information from adjacent holes, sometimes they included parts with low grades of gold, copper and silver, and left out some parts with good grades of these elements but located outside the selected limits of the veins.

5. Mineralized intersections in a hole that had no similar intersection in adjacent holes were not considered, and temporarily left aside. Later, they would be considered if found in new nearby holes, or would be studied when underground mining is carried out.

6. Their conclusions were frequently verified by a supervisor geologist.

7. The geological model was continuously updated and used for the selection of target areas to drill.

An example is provided here, showing the graphic log of hole LB-357 (Fig. 10 and Fig. 11) crossing Mascota-type veins. The log columns (Fig. 11) show the lithology, mineralization, silicification, hydrothermal alteration, and the grades of $\mathrm{Au}$, $\mathrm{Cu}, \mathrm{Ag}$, and of the indicator elements. The log also shows, at its right-hand side, the results achieved by the geologists, indicating the limits of the ore veins in the hole, their average 
grade and true thickness (obtained by using the angle of dip of the vein and hole inclination).

The limits defined by the geologists were used for developing the 3D wireframe models of the veins, which were used by a geostatistician to estimate the tonnages and average grades.
7.3 Initial exploration results of the southwestern concessions

Soon after taking over the exploration of the concessions acquired from Galway and Calvista (Galkine 2012, Moran and Sharma 2012), AUX confirmed that the San Juan Fault is a

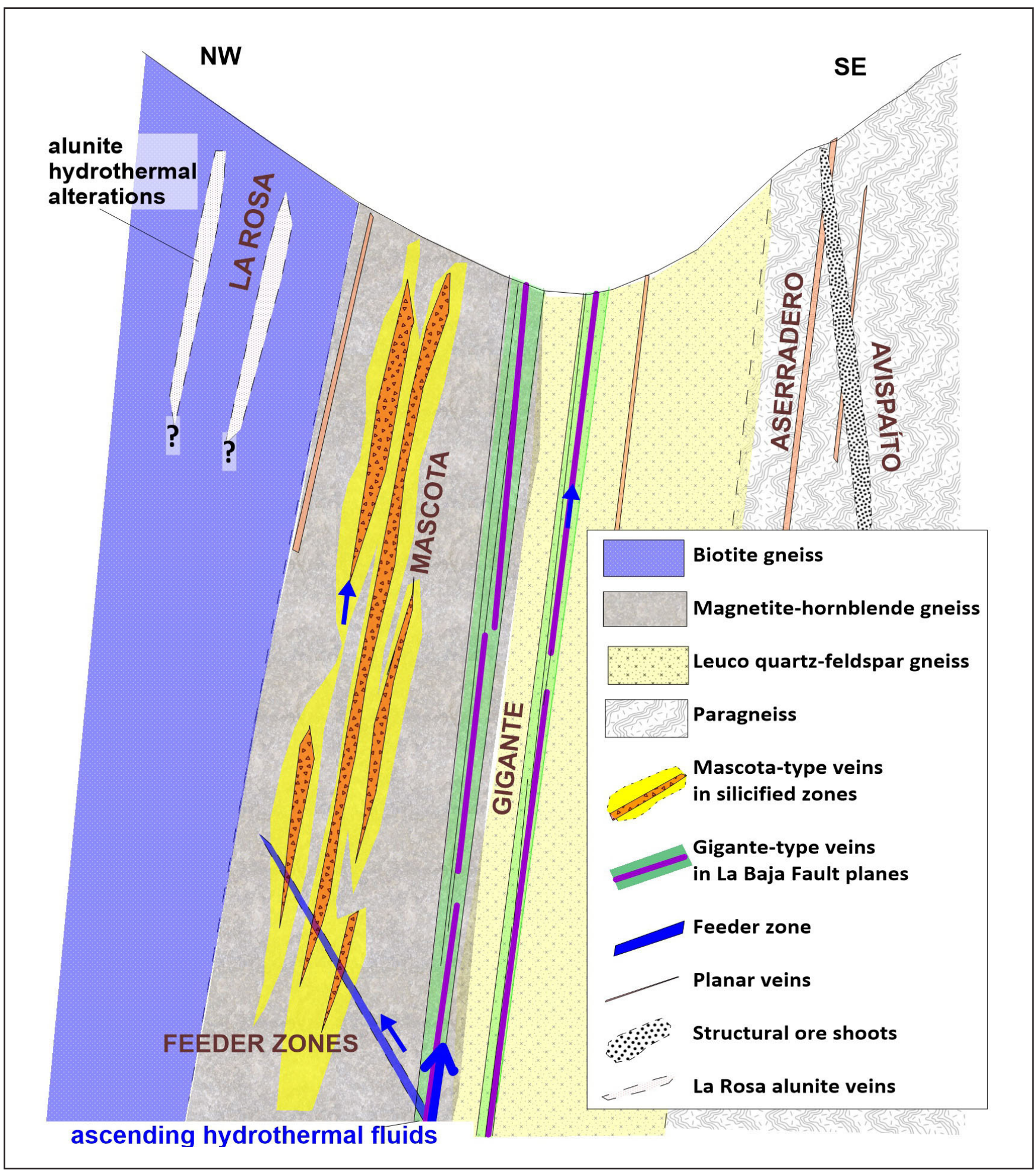

FIGURE 9. Model of the mineralization in the gneisses. The Gigante-type veins are formed in splays of the La Baja Fault directly from the ascending hydrothermal fluids. Part of the fluids penetrate laterally along feeder zones into the magnetite-hornblende gneiss, depositing the Mascota-type veins, and, further ahead, in biotite gneiss, forming the La Rosa-type veins. In the more compact and chemically resistant leucocratic gneiss, and in the Aserradero paragneiss, tabular veins are formed. At Avispaíto, an elongated and brecciated mass of the Aserradero gneiss also received mineralization. 


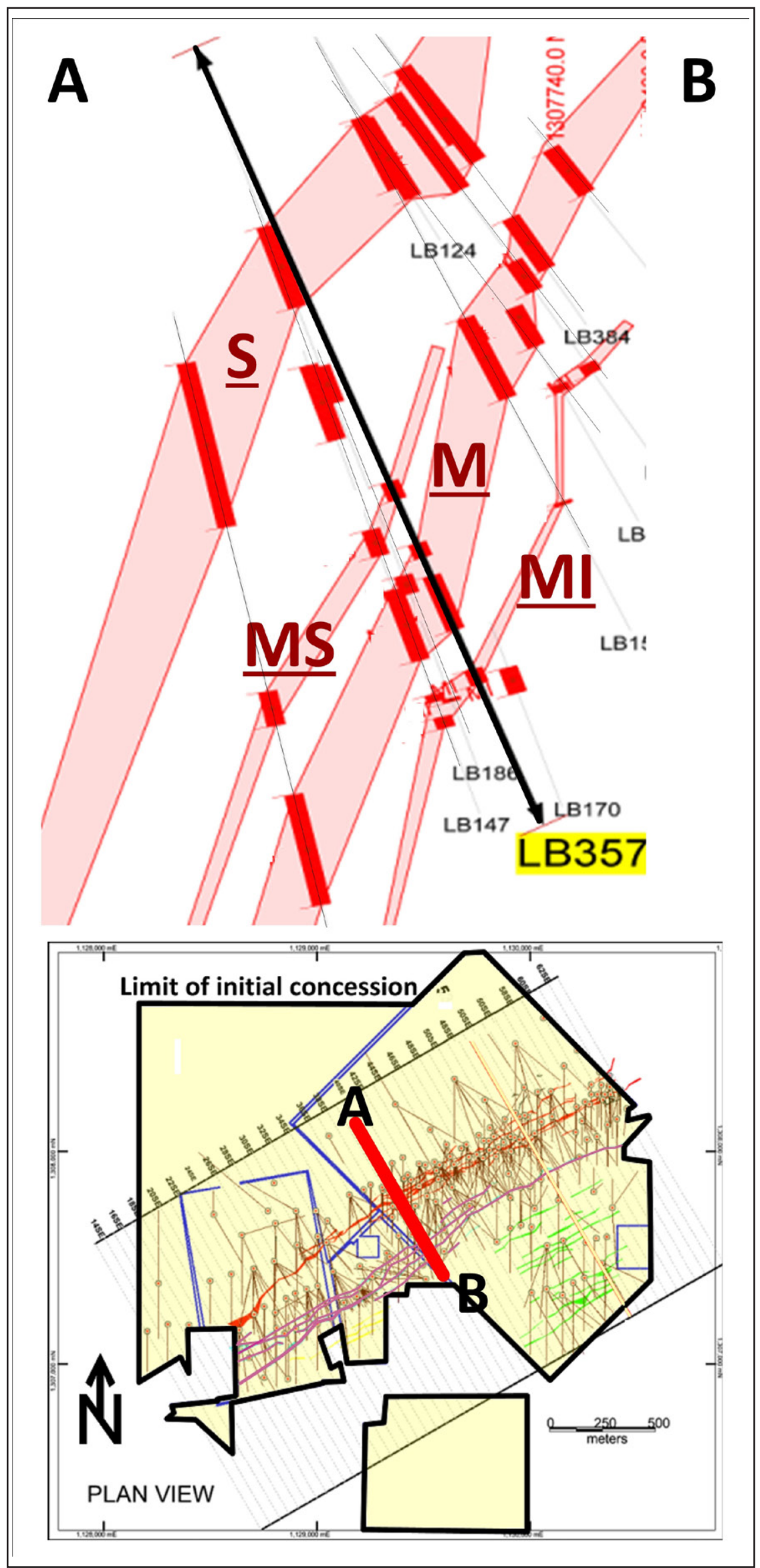

FIGURE 10. Section containing hole LB.357, one of the holes used to construct the wireframe model of the Mascota-type veins. In the section, the identified veins are the main Mascota (M), the Mascota Inferior (MI), the Mascota Superior (MS), and the Superior (S). Drill intercepts that were not laterally correlated were not used for wireframing. 


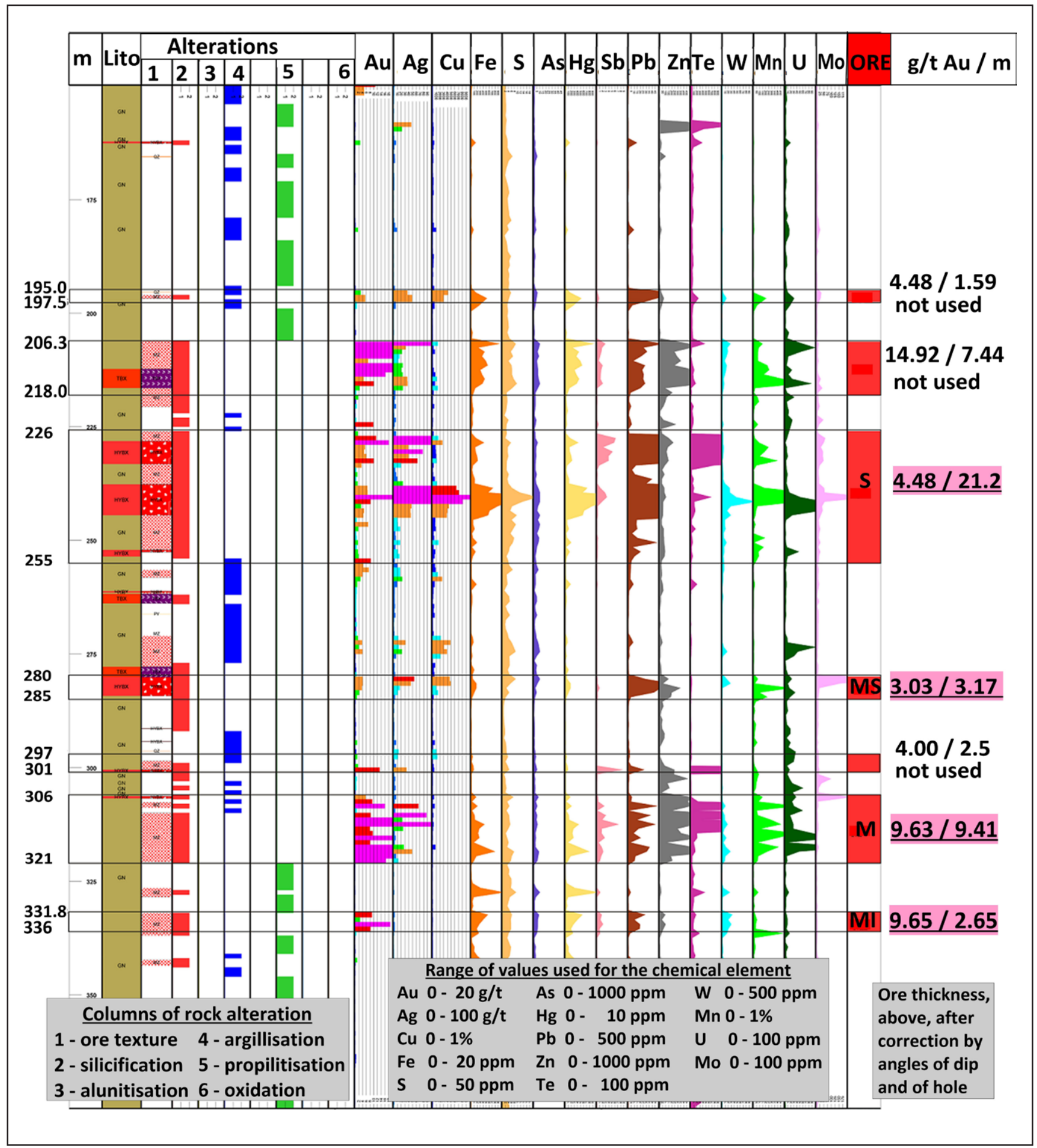

FIGURE 11. Hole LB.357, geological and chemical log used to delineate the veins for wireframing. After confirmation with adjacent holes, intercepts of veins M, MI, MS and S were accepted for the wireframe. Due to the lack of lateral correlation, intercepts marked as "not used" were not considered. The limits of the accepted intercepts, together with their average grades and true thickness are shown in the right margin of the figure.

thrust fault striking to the north, and dipping to the east, with upthrow of the block at the east.

Three important geological differences exist between the areas to the east and west of the San Juan fault (Fig. 12). Firstly, in the western portion, the contact between the magnetitehornblende gneiss and the leucocratic quartz-feldspar gneiss outcrops south of the La Baja Fault Zone, although at depth it might be at the north. Secondly, the Pié de Gallo quartz- monzonite intrusive forms an elongated body concordant with the La Baja Fault Zone, stopping before reaching the San Juan Fault, in contrast with the El Cuatro granite, which is seen at both sides of the fault (Fig. 4). Finally, and the most important difference, there is a remarkable difference in the depth of hydrothermalism of the magnetite-hornblende gneiss at the two sides of the San Juan Fault. Whereas to the east the alteration at the present topographical level is 
characterized by advanced chloritization, intense silicification and sulfidation, to the west, it is characterized by argillization and minor silicification, with the sulfidation occurring mainly as disseminations.

\section{Summary and conclusions}

In the north of Colombia, the Andes is made, on the west, of terranes brought in by the Nazca Plate, and, on the east, by blocks of continental rocks uplifted with the subduction of the Caribbean Plate under the continent (Fig. 1). Due to this uplift, a large portion of the Central and most of the Eastern Cordillera, the latter range only seen in Colombia, are made of Precambrian gneisses and migmatites, intruded by Mesozoic to Late Cenozoic granitic rocks.

In Colombia, the effects of the Caribbean Plate subduction are observed from the Caribbean coast to the Caldas Tear, an east-west zone defined by Vargas and Mann (2013) as marking the trace of the collision between the Caribbean and the Nazca Plates (Fig. 1, A and B). There are significant differences between the two sides of the tear. Notably, at the north, the lack of active volcanoes, the exposure of Precambrian rocks at high elevations of the Eastern and Central Cordilleras, and the presence of large mafic-ultramafic complexes (e.g. Cerro Matoso, in Colombia, and Loma de Hierro en Venezuela).
On addition, the better gold deposits of Colombia are located close to the Caldas Tear, more specifically to the north of Caucas and Bucaramanga, the two Colombian areas that present a large concentration of earthquakes (earthquakes nests) (Fig.1A). At the north of the Caucas earthquake nest, the deposits occur near Medellin, which is located nearly over the tear. At north of the Bucaramanga earthquake nest, the gold deposits appear at California and Vetas, which seems located along the western limit of the dominant southeastern structures of the Venezuelan Merida Andes.

Considering a possible link between these gold deposits and the subduction of the Caribbean Plate, it would be reasonable to consider that the water of the mineralizing hydrothermal fluids could have been liberated from watersoaked rocks, possibly serpentinites of the upper parts of the Caribbean Plate. That liberation would have occurred when this plate was reaching the zone of collision of the Caldas Tear, characterized by a large number of earthquakes and, possibly, intense fracturing. According to a model envisaged by Wilkinson (2013), the hot water liberated at depth would raise upwards, reacting with the percolated rocks and leaching them of gold and other metals. This possibility could explain the tremendous volume of hydrothermal fluids and metals necessary to produce the observed gold mineralization, in a system which is active until the present. The search for areas

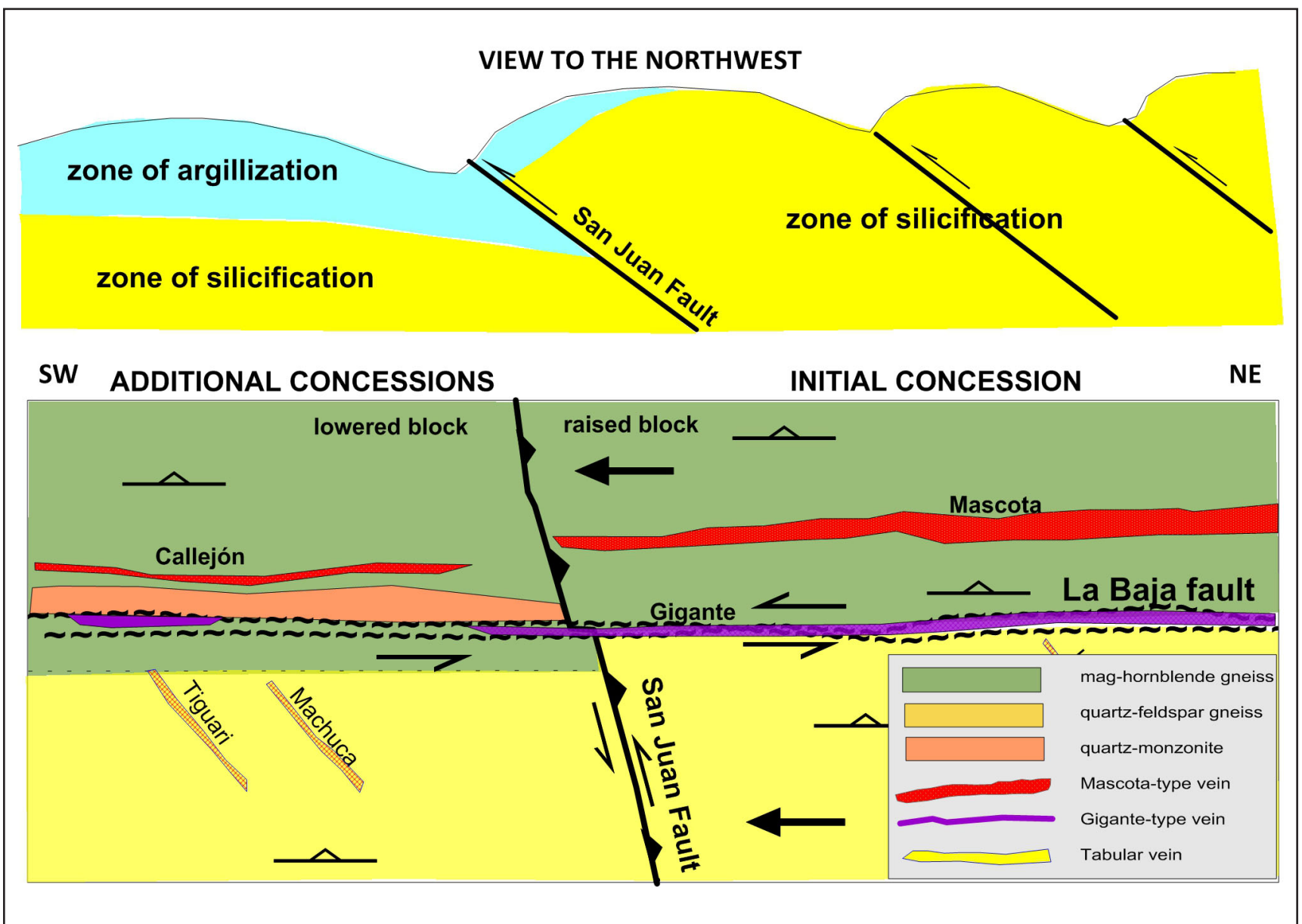

FIGURE 12. Schematic view of the main geological differences between the areas of the Initial and Additional Concessions, caused by the upthrow of the block to the northeast over the block to the southwest, along the San Juan Fault. As a consequence, in the area of the Additional Concessions, the intense silicification and brecciation that characterize the Mascota-type veins would occur at greater depths. In this area, since the gneisses dip to the northwest, the main splays of faults cross the magnetite-hornblende gneiss, improving the chances for more Mascota-type veins. 
with similar structures and surges of water may help to identify additional mineralization.

The area of California and Vetas has been submitted to tectonism and magmatism for a long period of time, possibly from the early Ordovician, as suggested by the $477 \mathrm{Ma} \mathrm{U}-\mathrm{Pb}$ zircon age on meta-diorite reported by Mantilla Figueroa et al. (2012).

The gneisses of the La Baja Fault Zone frequently present portions with migmatization, which are characterized by neosome with mineralogy, granulometry and texture quite similar to those of small granitic intrusives that occur in the area. For instance, the El Cuatro porphyritic granite, which intrudes the magnetite-hornblende gneiss, resembles the neosome of this gneiss, including the presence of pink porphyries of orthoclase. By its side, the neosome of the leucocratic quartz-feldspar gneiss is quite similar to the quartz-monzonite intrusives that intrude the gneiss.

These observations lead to the suggestion that these intrusives might represent accumulations of neosome that were mobilized and invaded their source rocks. For the El Cuatro-type granite intrusive, the age of $211 \mathrm{Ma}$ (Mantilla Figueroa et al. 2013) might indicate one age of mobilization of the neosome. Age determinations of the quartz-monzonites intruded in the leucocratic gneiss indicate a wider time frame for the intrusions. Ages of 8 to $11 \mathrm{Ma}$ have been reported (Leal Mejía 2011, Mantilla Figueroa et al. 2009 and 2011). For the Pié de Gallo intrusion, besides the 10 Ma crystallization age, inherited zircon ages of 200, 180 and 30 Ma were reported (Leal Mejía 2011), indicating repeated and superposed melting and intrusions. The same phenomena seem to have happened with the mineralization at California, with several cycles of hydrothermal alteration.

The hydrothermal fluids ascended in superposed pulses in the fault planes of the La Baja Fault Zone. Auriferous concentrations of silica and sulfides deposited in these planes constitute the Gigante-type veins. The fluids also penetrated and reacted with the country rock wherever fractures and other faults were open to them. Chemically reactive rocks, as the magnetite-hornblende gneiss, reacted with the fluids along planes of foliation possibly opened during tectonic stresses and earthquakes. Entering along these planes, the fluids first replaced feldspars, and some hornblende, by alunite, and then silicified the whole rock, forming tabular masses of silicification. Subsequent tectonic stresses and earthquakes would have broken these silicified rocks along planes of structural weakness parallel to the foliation of the gneiss, forming the breccia that host the gold, silver, copper and the associated metals of the Mascota-type veins. Weakly reactive but competent rocks, like the leucocratic gneiss, were opened to the hydrothermal fluids along fractures oblique to the fault direction, occupied by tabular veins.

For a long period of time, the area of California and Vetas called the attention of explorers for a possible copper porphyry system, but, with the possible exception of the intrusions of Angostura and Pié de Gallo, none was yet found. For exploration purposes, it is reasonable to accept that a large porphyry copper system could occur in the area, but deep below the present surface.

Exploring for gold in California, it is important to stay close to the La Baja Fault, which constitutes the main channel through which the hydrothermal fluids ascended. Then, the country rocks should be examined, for their capability to have had open spaces and to react with the hydrothermal fluids. The initial targets would be mineralization parallel to the foliation of reactive gneisses, like the magnetite-hornblende gneiss and the dark biotite gneiss, followed by mineralization in the fault planes themselves. Then, on a minor scale, potential exploration targets would be quartz veins in planes of faults and fractures in more competent rocks like the leucocratic quartz-feldspar gneiss. Intrusives like the quartzmonzonites might have veins along fractures and faults, but most of the mineralization will occur in small veins, veinlets and disseminations in tension fractures formed during the cooling of the intrusives. The sedimentary sequence that occurs at west of California is constituted essentially by shales, sandstones and conglomerates, albeit elsewhere it also presents limestones. This would be an ideal rock to receive the hydrothermal mineralization, but no gold mineralization associated with limestone was found in the area so far.

\section{Acknowledgements}

I am grateful to AUX for authorizing the publication of this geological note, except for figures of resources. I express my respect to the enthusiastic team of Colombian geologists for their dedication and hard work, as Martin Balcucho, Olivia Gonzalez, Margareth Guerrero Arias, Reynaldo Arenas Suarez, Sergio I. Gomez, Wilder Coronado Lizarazo, and others. I am also grateful to Prof. Dr. Steffen Hagemann of the University of Western Australia, Dr. Carlos Spier, from the University of Queensland, Australia, and Dr. Thomas Bissig, for suggestions given during the preparation of the manuscript. And last, but not the least, thanks also to Adriana Furtado Domingues Fonseca for a review of the article. The author thanks the JGSB reviewers (Prof. Lydia Lobato and PhD candidate Daniel Patias Guimarães) for their constructive and helpful reviews.

\section{References}

Aleman A., Ramos V.A. 2000. Northern Andes. In: Cordani U.G., Milani E.J., Thomaz Filho A., Campos D.A (ed.). Tectonic Evolution of South America. Rio de Janeiro, 31st International Geological Congress, 2000. Available on line at: http://rigeo.cprm.gov.br/jspui/handle/ doc/19419

Altman K.A., Sim R., Davis B.M., Prenn N.B., Elfen S.C., Fisher B.R. 2010. Canadian National Instrument 43-101 Technical Report: Preliminary Assessment La Bodega Project: Department of Santander, Colombia. Technical report (NI 43-101) - English (Jan 14 2011). Prepared by Samuel Engeering for Ventana Gold Corp. 226 p. Available on line at: https://www.sedar.com/GetFile.do?lang=EN\&docClass=24\&issuerNo $=00024683 \&$ issuerType $=03 \&$ projectNo $=01648578 \&$ docld $=2803707$ (accessed on 02 March 2021)

Bayona G., Cardona A., Jaramillo, C., Mora A, Montes C., Valencia V., Ayala C., Montenegro O., Ibañez-Mejia M. 2012. Early Paleogene magmatism in the northern Andes: Insights on the effects of Oceanic Plateau-continent convergence. Earth and Planetary Science Letters, 331-332, 97-111. https://doi.org/10.1016/j.epsl.2012.03.015

Bissig T., Clark A.H., Rainbow A., Montgomery A. 2015. Physiographic and tectonic settings of high-sulfidation epithermal gold-silver deposits of the Andes and their controls on mineralizing processes. Ore Geology Reviews, 65, 327-364. https://doi.org/10.1016/j.oregeorev.2014.09.027

Bueno J.A. 1955. Yacimientos de uranio y otros metales en la región de La Baja, Municipio de California, Departamento de Santander. Boletín Geológico, 3(3), 1-116. Available on line at: https://revistas.sgc.gov. co/index.php/boletingeo/article/view/144 / (accessed on 24 February 2021)

Cardona A. 2003. Correlações entre fragmentos do embasamento préMesozóico da terminação setentrional dos Andes Colombianos com 
base em dados isotópicos e geocronológicos. MSc Dissertation, Instituto de Geociências, Universidade de São Paulo, São Paulo, 149 p. https://doi.org/10.11606/D.44.2003.tde-07042015-090410

Cediel F., Shaw R.P., Cáceres C. 2003. Tectonic assembly of the Northern Andean Block. In: Bartolini C., Buffler R.T., Blickwede J. 2003. The Circum-Gulf of Mexico and the Caribbean: Hydrocarbon habitats, basin formation, and plate tectonics. AAPG Memoir 79 815-848.

Cordani U.G., Cardona A., Jimenez D.M., Liu D., Nutman A.P. 2005. Geochronology of Proterozoic basement inliers in the Colombian Andes: tectonic history of remnants of a fragmented Grenville belt. In: Vaughan A.P.M., Leat P.T., Pankhurst R.J. Terrane Processes at the Margins of Gondwana. Geological Society, London, Special Publications, 246, 329-346. https://doi.org/10.1144/GSL. SP.2005.246.01.13

Dörr W., Grosser J.R., Rodríguez G.I., Kramm U. 1995. Zircon U-Pb age of the Paramo Rico tonalite-granodiorite, Santander Massif (Cordillera Oriental, Colombia) and its geotectonic significance. Journal of South American Earth Sciences, 8(2), 187-194. https://doi.org/10.1016/08959811(95)00004-Y

Eco Oro Minerals Corp. 2018. Material Change Report; July 16, 2018. 2 p. Available on line at: $\underline{\text { https://www.sedar.com/GetFile.do?lang=EN\&doc }}$ $\underline{\text { Class }=14 \& \text { issuerNo }=00003568 \& \text { issuerType }=03 \& \text { projectNo }=0279583}$ 5\&docld $=4353549$ / (accessed on 02 March 2021)

Galkine V. 2012. Technical Report on the California Gold Project, California,

Santander Department, Republic of Colombia. NI 43-101 Technical Report and Resource Calculation. Prepared for Calvista Gold Corporation. Toronto, $134 \mathrm{p}$.

Godoy M., Farr G., McKittrick R, Engels J. 2012. Updated preliminary economic assessment on the Angostura gold-silver underground project, Santander Department, Colombia. Technical report (NI 43101) - English (Mar 27 2012). Prepared by Golder Associates Perú S.A for Eco Oro Minerals Corp. 269 p. Available on line at: https://www. sedar.com/GetFile.do?lang=EN\&docClass $=24 \&$ issuerNo $=00003568$ \&issuerType $=03 \&$ projectNo $=01878322 \&$ docld $=3076730 /$ (accessed on 02 March 2021)

Leal Mejía H. 2011. Phanerozoic gold metallogeny in the Colombian Andes: A tectono-magmatic approach. Thesis. PhD Thesis, Universitat de Barcelona, 989p.

Mantilla Figueroa L.C., Valencia V.A., Barra F., Pinto J., Colegial J. 2009. Geocronología U-Pb de los cuerpos porfiriticos del Distrito Aurífero de Vetas-California (Dpto de Santander, Colombia). Boletín de Geología, 31(1), 31-43.

Mantilla Figueroa L.C., Mendoza H., Bissig T., Craig H. 2011. Nuevas evidências sobre el magmatismo Miocénico en el distrito minero de Vetas-California (Macizo de Santander, Cordillera Oriental, Colombia. Boletín de Geología, 31(1), 43-58

Mantilla Figueroa L.C., Bissig T., Cottle J.M., Hart C.J.R. 2012. Remains of early Ordovician mantle-derived magmatism in the Santander Massif (Colombian Eastern Cordillera). Journal of South American Earth Sciences, 38, 1-12. https://doi.org/10.1016/j.jsames.2012.03.001

Mantilla Figueroa L.C., Bissig T., Victor V., Hart J.R. 2013. The magmatic history of the Vetas-California mining district, Santander Massif, Eastern Cordillera, Colombia. Journal of South American Earth Sciences, 45, 235-249. https://doi.org/10.1016/j. jsames.2013.03.006

Minesa. 2017. Proyecto Soto Norte. Bucaramanga, 2017. Available on line at: http://www.minesa.com/wp-content/uploads/presentacioncorporativa-minesa-empresarios-2017-sd.pdf. / (accessed on 25 February 2021)
Moran A.V., Sharma R. 2012. NI 43-101 Technical Report on Resources California Gold-Silver Project: Santander Department Colombia, South America. Technical report (NI 43-101) - English (Oct 26 2012). Prepared by SRK Consulting for Galway Resources. Available on line at: https://www.sedar.com/GetFile.do?lang=EN\&docClass=24 \&issuerNo $=00022464$ \&issuerType $=03$ \&projectNo $=01960229 \&$ doc $\underline{I d}=3209708 /$ (accessed on 24 February 2021)

Pagnacco P.F. 1962. Estudio minero genético del filón uranífero San Celestino (California, Santander). Geologia Colombiana, 1, 45-56. Available on line at: https://revistas.unal.edu.co/index.php/geocol/ article/view/30325 / (accessed on 24 February 2021)

Pulido N. 2003. Seismotectonics of the Northern Andes (Colombia) and the Development of Seismic Networks. Bulletin of the International Institute of Seismology and Earthquake Engineering, Special Edition, 69-76. Available on line at:

https://www.j-shis.bosai.go.jp/staff/nelson/papers/Pulido IISEE_2003. pdf. (accessed on 24 February 2021)

Ramos V.A. 2010. The Grenville-age basement of the Andes. Journal of South American Earth Sciences, 29(1), 77-91. https://doi.org/10.1016/j. jsames.2009.09.004

Reyes O.J.P., Sandoval S.A.R. 2013. Estudio del magmatismo Miocénico en el distrito minero de Vetas-California (Departamento de Santander, Colombia). Graduation work. Facultad de Ingenierias Fisicoquímicas, Universidad Industrial de Santander, Bucamaranga, 113p.

Rodríguez Madrid A.L., Bissig T., Craig J.R.H., Mantilla L.C.F. 2017. Late Pliocene High-Sulfidation Epithermal Gold Mineralization at the La Bodega and La Mascota Deposits, Northeastern Cordillera of Colombia. Economic Geology, 112, 347-374. https://doi.org/10.2113/ econgeo.112.2.347

Royero G.J.M., Vargas H.R. 1999. Geología del Departamento del Santander - 1:300.000. Bucaramanga, Ingeominas.

Servicio Geológico Colombiano. 2015. Catálogo de Dataciones Radiométricas de Colombia en ArcGis y Google Earth. Escala 1:1000.000. Available on line at: https://miig.sgc.gov.co/Paginas/ Resultados.aspx?k=230082105100024723000000000 (accessed on 24 February 2021).

Sillitoe R.H., Jaramillo L., Damon P.E., Shafiqullah M. and Escovar R. 1982. Setting, characteristics, and age of the Andean porphyry copper belt in Colombia. Economic Geology, 77(8), 1837-1850. https://doi. org/10.2113/gsecongeo.77.8.1837

Taboada A., Rivera L.A., Fuenzalida A., Cisternas A., Philip H., Bijwaard H., Olaya J., Rivera C. 2000. Geodynamics of the northern Andes: Subductions and intracontinental deformation (Colombia). Tectonics, 19(5), 787-81. https://doi.org/10.1029/2000TC900004

Gómez Tapias J., Nivia Guevara A., Mejía Jiménez D.M., Montes Ramírez N.E., Ospina J.S., Osorio Naranjo J.A, Tejada AVELLA M.L, Penagos M.M., Gaona-Narvaez T., Diederix H., Uribe Peña H. 2006. Mapa Geológico de Colombia. Escala 1:2'800.000. Bucaramanga, Ingeominas, Servicio Geológico. https://doi.org/10.13140/ RG.2.2.35322.29127

Vargas C.A., Mann P. 2013. Tearing and Breaking Off of Subducted Slabs as the Result of Collision of the Panama Arc-Indenter with Northwestern South America. Bulletin of the Seismological Society of America, 103(3), 2025-2046. https://doi.org/10.1785/0120120328

Ward D.E., Goldsmith R., Cruz B.B, Restrepo J., Hernan A. 1970. Mineral resources of the southern half of Zone III Santander, Norte de Santander, and Boyaca, Colombia. USGS open file 70-359. https://doi. org/10.3133/ofr70359

Wilkinson J.J. 2013. Triggers for the formation of porphyry ore deposits in magmatic arcs. Nature Geoscience, 6, 917-925. https://doi. org/10.1038/ngeo1940 